\title{
INTER DUOS PONTES O ottońskiej fundacji ku czci św. Wojciecha na Wyspie Tybrowej
}

Istnieje w Rzymie tradycja, że Bazylika San Bartolomeo al Isola Triberina to kościól wzniesiony przez cesarza Ottona III na fundamencie przywiezionych z Gniezna w roku tysięcznym relikwii św. Wojciecha i pierwotnie noszący jego tytuł. Wewnątrz świątyni znajduje się ustawiona pośrodku schodów, prowadzących z nawy głównej do absydy ołtarzowej, romańska cembrowina studzienna $\mathrm{z}$ marmuru o odcieniu i połysku kości słoniowej z domniemanym wyobrażeniem św. Wojciecha ${ }^{1}$. Zadomowieni zaś przy tej bazylice od roku 1536 franciszkanie chętnie zwracają uwagę, zwłaszcza pielgrzymom z Polski, Czech i Słowacji, na relikwiarz „con brachio Sancti Adalberti”, umieszczony pod ołtarzem w kaplicy (na lewo od absydy) pod wezwaniem słowiańskiego świętego. Mniej znane są podziemne sklepy bazyliki z fragmentami romańskiego muru Ottońskiej budowy. Jest tam (pod absydą) krypta z kilkoma kolumienkami, z których dwie zachowały białe, piaskowcowe kapitele kształtu trapezoidalnego, zwane czasem „campitelli aquilatti” od zdobiących je płaskorzeźbionych orłów (a może gołębi) z rozpostartymi skrzydłami. Zniszczona w XVI wieku wodami rzeki, dziś tylko częściowo odzyskała oryginalny wygląd. Może jeszcze modo graeco położony fresk Bogurodzicy w absydzie kaplicy na prawo od głównego ołtarza, odkryty w 1904 roku — zdaniem niektórych historyków sztuki można wiązać $\mathrm{z}$ najstarszą, ottońską fazą istnienia tej świątyni ${ }^{2}$. Inny relikt

${ }^{1}$ Studzienka ta - pozetto - zwana też przez Włochów collo lub anello została doskonale omówiona w rozprawie A. Gie ys ztor a: Rzymska studzienka ze św. Wojciechem z roku ok. 1000, [w:] Sztuka i historia. Ksiega pamiatkowa ku czci prof. M. Walickiego, Warszawa 1966, s. 22 -29 .

${ }^{2}$ A. Manoz (Un affresco scoperto a S. Bartolomeo all'Isola in Roma, „L'Arte” 8:1905 s. 60 -62), a za nim R. von M a r le (La peintura romana au mayen age, Strassburg 1917) - w reprezentowanym przez to malowidło typie odigetria o wyraźnie bizantyńskiej urodzie, ciemnej karnacji, mocno obrysowanym konturze twarzy i rąk, dopatrują się wpływu ikon bizantyńskich. Wiele z nich bowiem znalazlo się w Rzymie w związku z ikonoklazmem na fali emigracji ze Wschodu, co wywarło imponujący wpływ na malarstwo włoskiego ducenta. Autorzy ci datują malowidło na początek wieku XII. Ostatnio jednak, przy okazji restauracji fresku, przeprowadzonej w związku z generalnymi pracami badawczo-konserwatorskimi bazyliki w latach $1973-1976$, rewindykowano ten fresk dla czasów ottońskich; zob. A. S i s t i, La basilica di S. Bartolomeo all'Isola Tiberina, Roma [b.r.], s. $9-10,82-83$ (reprodukcja). 
tamtych czasów to stojąca w transepcie, okazała, brązowa, okrągłego kształtu waza pochodzenia egipskiego lub syryjskiego, za czym przemawiają jej arabskie dekoracje. To w niej, według tradycji, Otton III miał sprowadzić z Benewentu relikwie św. Bartłomieja, apostoła i męczennika ${ }^{3}$. Poza tym trudno tu szukać „świadków” Krescencjuszowych i Ottońskich czasów. Wszystko należy tu już do epok późniejszych. Usytuowanie bazyliki na Wyspie Tybrowej narażało ją na niszçzące działanie powodzi, a kolejne, często po sobie następujące odbudowy wpływały na zatarcie czytelności poszczególnych faz, sprawiając dziś trudności w datowaniu ${ }^{4}$. Zwłaszcza trzy katastrofalne wylewy w ciągu XVI wieku spowodowały konieczność przeprowadzenia znacznych prac rekonstrukcyjnych. Wówczas nadano bazylice obecny, barokowy wystrój. W absydzie głównej ustawiono antyczną wannę z porfiru, pochodzącą zapewne $\mathrm{z}$ ruin którychś term, deponując w niej relikwie św. Bartłomieja a w portyku, na architrawie wspartym na czterech starożytnych kolumnach z czarnego granitu, odkuto inskrypcję: Hac basilica requiescit corpus $S$. Bartolomei Apostoli. Franciszkańska treść hagiograficzna malatur wnętrza, pędzla A. Carracciego oddala jeszcze bardziej od ottońsko-wojciechowej tradycji tego miejsca. Kult Apostoła zdominował pamięć słowiańskiego świętego.

Mimo tak licznych modernizacji pozostał przecie najogólniejszy kształt bazyliki. Zwłaszcza czternaście granitowych, antycznych kolumn z korynckimi kapitelami, dzielących jej wnętrze na trzy nawy, stanowi trwały trzon cesarskiej budowy ${ }^{5}$. Przypomnieniu zamierzchłych dziś początków tej fundacji sprzed bez mała tysiąclecia ma służyć niniejsze opracowanie.

Za historyczny punkt wyjścia naszych rozważań można przyjąć rok 1000, a ściślej — pielgrzymkę cesarza Ottona III do Gniezna, będącą następstwem śmierci Wojciecha Sławnikowica podczas usiłowań prowadzenia misji w Prusach, dnia 23 kwietnia 997 roku. Chcąc jednak wyraźnie ukazać, czym w zamy-

${ }^{3}$ Zob. A. Si s ti, jw., s. 10, 66 - 67. Naczynie to w roku 1892 zniknęlo i uznane za zaginione, ale w roku 1985 się odnalazło.

${ }^{4}$ I tak nie jest pewne czy z czasów odbudowy papieża Paschalisa II (1099 - 1118) czy Aleksandra (1159-1181) lub może o wiele wcześniejszych pochodzi czteropiętrowa romańska, górująca nad bazyliką i całą wyspą kampanila, prześwietlona niegdyś (częściowo dziś zamurowanymi) bi- i triforiami. V. Galzio i G. Za nder (Le chiese di Roma dall XI al XVI secol. Roma Cristiana, t. 4, Bologna 1963, s. 43), a również E. B ull et t i (La Basilica di San Bartolomeo all'Isola, Roma 1926, s. 226) - odnoszą ją do początków XII wieku. Z kolei A. Gi e y s z t or (Rzymska studzien$k a \ldots$, s. 22) nie wyklucza, że podobnie jak trójabsydowe zamknięcie wschodnie bazyliki, także i wieża pochodzić może $\mathrm{z}$ ottońskiej fazy budowy. Podobnie $\mathrm{z}$ mozaiką $\mathrm{z}$ frontonu, której fragment wyobrażający błogosławiącego Chrystusa w złotej tunice, w krzyżowym nimbie i z księgą („Ego sum via, veritas et vita" - Jan 14,6) i przywodzący na myśl monumentalne mozaiki absydalne z Monreale i Cefalu - której fragment zachował się za przeszkleniem ponad portykiem bazyliki. A. Ma nzon i (Frammento di musaico a S. Bartolomeo all'Isola in Roma, „L'Arte” 7:1904 s. 516) opowiada się za rokiem ok. 1180. Natomiast V. B alzi o i G. Zan de r (jw., s. 188) cofają datację mozaiki na czasy Innocentego II $(1130-1143)$. Również z czasów którejś dwunastowiecznej odbudowy pochodzą fragmenty mozaikowych posadzek w stylu Kosmatów.

${ }^{5}$ Bazylika ta doczekała się, nie licząc literatury rozproszonej, kilku syntetycznych opracowań. Do cytowanych wyżej dodajmy: A. Pazini, L'antica chiesa di San Adalberto, "Capitolium" 10:1934; C. Ce c c h elli, la basilica ottoniana dell' Isola Licaonia. Studi e documenti sulla Roma sacra, t. 2, Roma 1951, s. 29-89. 
śle Ottona była ta rzymska fundacja ku czci męczennika i cesarskiego przyjaciela, czym miał być jego kult dla Rzymu i Italii, a czym dla całego cesarstwa, trzeba nam ją ukazać w szerszym kontekście szybko po sobie następujących zdarzeń na schyłku tamtego tysiąclecia.

Rzymski genius loci sprzyja myśleniu kategoriami universum. W kręgu tutejszej arystokracji w czasach ottońskich wykształcił się już system polityczny zmierzający do samodzielności Rzymu wobec cesarstwa, jak też papiestwa, a nie pozbawiony - jak się zdaje — szerszych horyzontów politycznych. Ten „antylongobardzki” Rzym reprezentował ród Krescensjuszów oraz ich rywale $\mathrm{z}$ rodu Alberyka. Rzym sam wciąż miał świadomość swej wielkiej przeszłości. Wilczyca kapitolińska, pod którą odbywano sesje sądowe, była nadal symbolem Romy, a przeniesiony spośród ruin Forum pod Lateran posąg Marka $\mathrm{Au}$ reliusza, choć udawał teraz Konstantyna Wielkiego — był świadkiem świetnej przeszłości. Od czasów starożytnych trwał też podział miasta na 14 dzielnic administracyjnych. Zamieszkująca je ludność, zamknięta we względnie bezpiecznym pierścieniu, wciąż reperowanych, potężnych murów aureliańskich stosunkowo łatwo ulegała wpływom miejscowej arystokracji. Jej zaś siła gruntowała się na dobrach ziemskich z zamkami poza Rzymem oraz na handlowo-kupieckiej pozycji w mieście, jak również na trzymaniu w ręku najważniejszych stanowisk. Niejednokrotnie też za kulisami tej antycesarskiej, rzymskiej polityki Krescencjuszów krył się sekretny udział dyplomacji znad Bosforu.

Od zażegnania wypadków spowodowanych przez Krescencjusza I w 974 roku trwał pozorny spokój. Śmierć Ottona II (983 r.) i okres regencji cesarzowej Teofano - matki nieletniego Ottona III (ur. 980 r.), a później cesarzowej Adelajdy, jego babki - sprzyjał umocnieniu Rzymu. Synowie Krescencjusza I: Krescencjusz II i Jan, wspólnie sprawowali prefekturę w mieście, formalnie byli więc mandatariuszami cesarskimi; Jan ponadto był szatnym papieskim; i jako ów vestiarius trzymał skarb. W ten sposób Krescensjusze mieli kontrolę nad całokształtem spraw ówczesnej polityki rzymskiej. Wreszcie siedemnastoletni Otton przybył w roku 996 do Rzymu i w uroczystość Wniebowstąpienia Pańskiego (21 maja) został ukoronowany na cesarza przez osadzonego na papieskim tronie krewniaka, Brunona, który przybrał imię Grzegorza V. Wówczas to cesarz zbliżył się do Wojciecha przebywającego właśnie w awentyńskim klasztorze św. Bonifacego i Aleksego. Wojciech opuściwszy biskupstwo praskie złożył tu benedyktyńskie śluby zakonne i snuł plany misji in partibus infidelium. Wkrótce jednak bunty wśród Słowian połabskich zmusiły cesarza do powrotu za Alpy, a w podróży tej miał mu częściowo towarzyszyć udający się do Galii Wojciech. W lutym 998 roku cesarz był z powrotem w Rzymie, ale nie wjeżdżał doń jak poprzednio ,ze wspaniałym orszakiem”, lecz musiał go orężnie odzyskiwać. Akcja pacyfikacyjno-represyjna trwała dwa miesiące, a mówiąc słowami Długosza, „przy tej sposobności „[ottoński] orzeł stracił wiele piór". 
Pod nieobecność cesarza Krescensjusz na miejsce zegnanego Grzegorza V wprowadził antypapieża Jana Filogatosa, a teraz stawiał Ottonowi opór w potężnym mauzoleum Hadriana służącym w tamtej epoce za twierdzę, jako tzw. zamek Teodoryka lub zamek Anioła. W końcu jednak zdradzony Krescencjusz został pojmany, a na rozkaz cesarza ścięty i powieszony za nogi ( 28 kwietnia 998 r.) „wielki budząc tym postrach wśród wszystkich przytomnych”. Ratującego się ucieczką Filogatosa „ci, co pozostali wierni Chrystusowi i cesarzowi pozbawili [...] języka, oczu i nosa”, zaś „papież Grzegorz został intronizowany $\mathrm{z}$ wielkimi honorami, a cesarz panował odtąd bez żadnych zakłóceń"6. Ale wypadki rzymskie roku 998 były mocnym i trwałym w skutkach wstrząsem moralnym dla Ottona.

Prawdą jest, iż „czlowiek ma to do siebie, że niepodobna go wyczerpać historycznie"7, musimy jednak próbować rozumieć motywy i pobudki przedsięwzięć i działań. Otóż krwawy rok 998 był dramatem Rzymu Krescencjuszów, ale i dramatem cesarza. Wyraziło się to w formule dyplomatycznej cesarskiego logothety, akcentującej czas „quando Crescencius decollatus suspensus fuit"8. Otton, darzący Krescencjusza przyjaźnią i względami, poczuł się zmuszony wydać go na okrutną śmierć. Nie był drugim Kaligulą, ale też nie był wyzutym z poczucia realizmu marzycielem ${ }^{9}$. Krescencjusz, przeciwstawiając się Ottonowi, we własnym mniemaniu walczył, podobnie jak jego ojciec, przeciw Niemcom, nie rozumiejąc nie dość jeszcze wyraźnie zarysowanej koncepcji nowego imperium. Że zaś Otton wciąż postępował konsekwentnie w myśl przyjętej zasady egalitaryzmu etnicznego, świadczy fakt, że i po roku 998 nie wytracił Krescencjuszów, lecz nadal się na nich opierał, udzielając im kredytu swego zaufania, choć wprowadzał też „obcych” (np patrycjusz Ziazo - Ciazo). Jednak gwiazda Krescencjuszów w Rzymie tymczasem przygasła.

Pośród wiru tych zdarzeń doszła do cesarza wiadomość o śmierci przyjacie-

${ }^{6}$ Kronika Thietmara (wydanie bilingwiczne z tłumaczeniem, wstępem i komentarzem M. Z. Jedlickiego), Poznań 1953, s. 184 (dalej: Kronika Thietmara). Dokładniej o tych sprawach zob.: F. Gre go ro wi u s, Storia della citta di Roma nel Medio Evo, t. 2, Roma 1900, s. 105 - 146; S. Za k rzew sk i, Opactwo benedyktyńskie śś. Bonifacego i Aleksego na Awentynie w latach $977-$ 1088, Kraków 1903; P. B r'e z z i, Roma e l'impero medievale (774-1252), [w:] Studia di Roma, t. 10, Bologna 1947, s. $164-188$; B. Z i e n t a r a, Świat narodów europejskich. Powstawnie świadomości narodowej na obszarze Europy pokarolińskiej, Warszawa 1985, s. 253 - 285. W tych opracowaniach szczegółowa literatura.

${ }^{7}$ K. Wo j tył a, Brat naszego Boga, [w:] tegoż, Poezje i dramaty, Kraków 1986, s. 113.

${ }^{8}$ Monumenta Germaniae historica - Diplomatum regum et imperatorum Germaniae tomus II pars posterior: Ottonis III diplomata, Hannoverae 1893, s. $710(\mathrm{nr} 285)$ - dalej cytuję: MGH Diplomata Ottonis III.

9 Thietmar stwierdza, że „niedostatek lat pokrywal silnym charakterem i gorliwością" (Kronika Thietmara, s. 180), a też, że ,jakkolwiek na zewnątrz udawał wesołość, to jednak w sumieniu niejeden wyrzucał sobie uczynek i w ciszy nocnej ciągle odprawiał pokutę przez czuwania i długie, strumieniami łez przeplatane modlitwy. Często pościl [...] i wielką hojność okazywał w jałmużnach" (jw., s. 212 - 213). W piśmiennictwie polskim G. Lab u d a (Studia nad początkami państwa polskiego, Poznań 1946, s. 306 - 307) oraz K. T y mi e n i e c k i (Z dziejów tworzenia się Europy w $X$ wieku, Poznań 1955, s. 153) wskazują na realizm i konkretyzm polityki Ottona III. 
la - Wojciecha, poniesionej w czasie misji w Prusach ${ }^{10}$. Wiadomość ta musiała na Ottona mocno oddziałać i ożywić wspomnienie chwil, gdy w awentyńskim klasztorze „rozmawiał często ze świętym Wojciechem i przestawał z nim po przyjacielsku, chętnie słuchając jego słów”. Ożyło też wspomnienie „poufnego obcowania przyjaciół w dzień i w nocy" w Nadrenii 996 roku, zwłaszcza w Moguncji ${ }^{11}$. A jeśli nie jest legendą informacja Kosmasa, jakoby św. Wojciech w Wielkanoc tegoż roku odprawiał mszę św. pożegnalną w kaplicy pałacowej w Akwizgranie ${ }^{12}$, po której obaj przyjaciele ostatecznie się rozstali- to Otton i w późniejszych faktach miałby kanwę dla swych wspomnień. Zaraz też podjęto prace redakcyjne nad żywotem męczennika. Prowadzono je w środowisku awentyńskim, którego pragnienie zapewne zbiegło się z inicjatywą cesarską i nie bez udziału jego samego. Opactwu mogło zależeć na dorzuceniu „promyka chwały” przez spisanie czynów człowieka Bożego, który przecie był członkiem tego konwentu. Z kolei zaś żywot taki i męczeńska śmierć przyczyniały się do gruntowania autorytetu i sławy Ottona jako przyjaciela świętego męczennika ${ }^{13}$.

Jednakże nie tylko o to chodziło. Wojciech za życia pozostawał w rozgałęzionych kontaktach i związkach przyjaźni z członkami rodu Krescencjuszów, dobroczyńców awentyńskiego klasztoru. Popularność jego osoby w kręgach elity rzymskiej była znaczna i żywa; „pamięć ta — zauważa S. Zakrzewski równie droga obydwu partiom w Rzymie [Krescencjuszów i cesarskiej] mogła wytworzyć rodzaj duchowego łącznika i rozpamiętywanie takiej postaci mogło przynieść załagodzenie przeszłości i ukojenie"14. Ten duch pojednania unosi się nad rzymską redakcją Vita prior. S . Zakrzewski zwrócił też uwagę, że kult

${ }^{10}$ Kronika Thietmara (s. 182) świadczy, że „wieść o tym dotarła do cesarza w Rzymie”. Musiato to zatem nastąpić po 20 lutego 998 r., kiedy powrócił tu zaa Alp, a wiadomość tę przywiózł wyslany przez Bolesława Chrobrego brat przyrodni biskupa i świadek jego męczeństwa Radzim-Gaudenty.

${ }^{11}$ Sw. Wojciecha żywot pierwszy, [w:] Piśmiennictwo czasów Bolestawa Chrobrego, przetlumaczyl K. Abgarowicz, Warszawa 1966,s. 67-68. O osobistych związkach cesarza z Wojciechem Sławnikowicem i jego wpływie na Ottona zob.: S. Zakrzewski, Bolesław Chrobry Wielki, Lwów 1925, s. 106, 113, 115; T. Silnick i, Sw. Wojciech, czlowiek i święty oraz jego działalność, [w:] Swięty Wojciech 997 - 1947. Księga pamiq̨tkowa, Poznań (1947), s. 59 nn. Pelną literaturę cytuje Hagiografia polska. Stownik bio-bibliograficzny pod red. o. R. Gustawa, t. 2, Poznań 1972, s. $597-601$.

${ }^{12}$ Zob. Ko s m a s, Kronika Czechów, przekład, wstęp i komentarz M. Wojciechowska, Warszawa 1968, s. 152. J. Karwasińska (w swym komentarzu do: Piśmiennictwo czasów Bolestawa Chrobrego, Warszawa 1966, s. 71 - 72) powyższą informację uważa za "godną uwagi”.

${ }_{13}$ Taka m. in. funkcja dzieła uwyraźniła się w finale ottońskiej — rzymskiej redakcji Vita prior, brzmiącym prawie jak kancelaryjna formuła datacyjna: „Passus est autem sanctus et gloriosissimus martyr Christi Adalbertus [...] imperante rerum domino Ottonum tertio, pio et clarissimo cesare" (MPH series nova, t. IV/1, Warszawa 1962, s. 47). Wszelkie sprawy związane z Vita prior, gruntownie zbadane, znalazły wyraz w obfitej literaturze, którą zestawia Hagiografia polska..., t. 2 , s. 589 - 595. Szczególnie zob.: W. Kęt r z y ńs k i, Najdawniejsze żywoty św. Wojciecha i ich autorowie, Kraków 1898; J. K a rw a sińs k a, Studia krytyczne nad żywotami św. Wojciecha biskupa praskiego, „Studia Źródłoznawcze” 2:1958 s. 41-79; tamże, 4:1959 s. 10-32; tamże, 9:1964 s. 15 -45; tamże, 11:1966 s. 67-78.

${ }^{14}$ S. Zakrzews ki, Opactwo..., s. $81-82$ (tutaj też dokładniej o pobycie Sławnikowica w awentyńskim klasztorze i o jego rzymskich koneksjach). 
św. Wojciecha, szczepiony przez Ottona w czasie jego italskich podróży w latach 998 - 999 trzyma się gruntów - co naturalne - benedyktyńskich, ale pochodzących z nadań i darowizn ludzi z partii Krescencjuszów, co zdaniem autora nie było przypadkowe ${ }^{15}$. Podejmując zawartą $w$ tym sugestię, wypada stwierdzić, że fundacje te miały służyć odbudowie dobrych stosunków w Rzymie i konsolidacji Italii. Kult św. Wojciecha miał być kamieniem węgielnym zgody cesarza z Krescencjuszami, a zarazem istotnie wpisywał się w całokształt ottońskich planów uniwersalnych.

Redakcję $\dot{Z}$ ywota rozpoczęto najwcześniej wiosną 998 r., a przed 2 grudnia 999 musiała już być ukończona ${ }^{16}$. Równocześnie dojrzewał i zaczynał tu wyraźnieć ottoński program renovatio Imperii Romani, co-zdaniem Thietmararóżni różnie oceniali" ${ }^{17}$. Od kwietnia 999 r. współpracownikiem cesarza w realizacji tego programu był nowy papież - Sylwester II (Gerbert z Aurillac), który już jako rektor szkoły katedralnej w Reims, a następnie z woli cesarza arcybiskup pierwszej po Rzymie Rawenny, dał się poznać jako umysł wybitny, prawdziwie renesansowy.

Tak więc po dramacie Krescencjuszów zaczął szybko dojrzewać program polityczny Ottona III — program, którego osią myślową było wspomnienie tragicznej postaci cesarskiego przyjaciela. Żywot formułował pewne elementy tego programu, wywodzące się z osobistych nauk świętego, i z tego względu ma on wydźwięk również polityczny. Redagowany z woli cesarza i autoryzowany przez papieża $\dot{Z}$ ywot wskazywał na przykład męża Bożego, który uosabiał fanatyczną, lecz czystą ideę pracy misyjnej, zupełnie nie znaną ówczesnemu światu, a diametralnie różną od polityki misyjnej Kościoła niemieckiego. Natomiast rozdział 23. to rodzaj traktatu moralnego, kreślącego wizerunek idealnego władcy o typie religijności benedyktyńskiej, przejętego duchem apostolstwa. Żywot rozszerzał horyzont ówczesnego orbis terrarum, wskazując na obszar zwłaszcza „Slavonii” i jej potencje. A wreszcie utwór ten akcentował centralne miejsce Rzymu w ówczesnym świecie zgodnie z odczuciem cesarza i jego interpretacją tego faktu. Stwierdzono tam, że „Rzym jest i nazywa się stolicą świata i królową miast, on jedynie czyni królów cesarzami; ponieważ tuli

15 Zob. tamże, s. $82 \mathrm{nn}$; T. Du n in - W ą s ow i cz, Wezwania św. Wojciecha w Europie okoto roku 1000, „Studia Warmińskie” 19:1982 s. $31 \mathrm{nn}$.

${ }^{16}$ W tym dniu Radzim-Gaudenty podpisał dokument cesarski już jako ,archiepiscopus sancti Adalberti martyris" (MGH Diplomata Ottonis III, s. 768, $769 \mathrm{nr} 339$ ). Musiał więc być już po konsekracji i inwestycji. Było to zatem również po synodzie rzymskim, na którym de iure kreowano arcybiskupstwo gnieźnieńskie i wydano zapewne odpowiedni dokument (zabrany następnie do Gniezna), choć źródła o nim milczą (zob. Z. Kozł ow s k a - B udk ow a, Repertorium polskich dokumentów doby piastowskiej, Kraków 1934, s. 5-6 nr 4). Wypada przyjąć, że uznanie bpa Wojciecha świętym męczennikiem musiało nastąpić przed kreowaniem dedykowanego mu arcybiskupstwa, tego zaś podstawą był jego Żywot, autoryzowany przez papieża. Żywot miał stać się odtąd elementem aparatu liturgicznego, służącym kultowi nowego świętego.

17 Kronika Thietmara, s. 210. Na jednoczesność tych poczynań zwrócił uwagę Z. Woj cie ch ow s k i Patrycjat Bolestawa Chrobrego, [w:] tegoż: Studia historyczne, Warszawa 1955, s. 104. 
w swym łonie ciało księcia apostołów, słusznie powinien też ustanawiać władcę ziemskiego"18.

Uwielbienie Ottona III dla Rzymu generalnie nie było niczym nowym. To tradycja dawniejsza i w kręgu wczesnośredniowiecznej elity Zachodu powszechna. Jednak nigdy dotąd Rzym w systemie władzy wczesnośredniowiecznego cesarstwa nie spełniał takiej roli, jaką mu wyznaczono teraz. Poprzednicy Ottona III, od Karola Wielkiego poczynając, przybywali do Rzymu, by odbyć tu cesarską koronację i po udzielonej im przez papieża gościnie powracali za Alpy, szanując Rzym jako „patrimonium Sancti Petri”. Otton III natomiast pragnął tu uczynić faktyczną stolicę monarchii uniwersalnej i stałą rezydencję cesarstwa, nazywając Rzym „nostra urbs regia”19. Dlatego też za pośrednictwem formuł dyplomatycznych swego logothety Leona $\mathrm{z}$ taką pasjął potępiał machinacje dawnych papieży, upostaciowane w sławnym falsyfikacie tzw. darowizny Konstantyna, a mające na celu pozbawienie cesarza jego prerogatyw w Rzymie i Italiii ${ }^{20}$. Niepokoiło to, budziło nieufność i groziło gwałtownością reakcji.

${ }^{18}$ Piśmiennictwo..., s. $64-65$ (zob. też s. 52 nn); brzmienie łacińskie tegoż por.: MPH series nova, t. IV/1, s. 32. Powtórzenie tych sformułowań znajdujemy też w jednym z dyplomów (zob. MGH Diplomata Ottonis III, s. $818 \mathrm{nr} 389$ ).

${ }_{19}$ Zob. MGH Diplomata Ottonis III, s. $819 \mathrm{nr} 389$. Dawnmiejszy pogląd, wywodzący się ze związanej z Awentynem, a przeniesionej z Bizancjum, nazwy Blacherna oraz oparty o formulę loci w niektórych dokumentach ottońskich: „Actum Romae in palacio monasterio” (określenie wiązane z klasztorem śś. Bonifacego i Aleksego) jakoby na tym wzgórzu miał się znajdować pałac Ottona III, upadł na rzecz Palatynu. palatyn był tradycyjną rezydencją cesarzów, gdzie może już Otton I zacząl wznosić nowy palac. Wiemy wszak, że w roku 961 „Fuldensem abbatem ad construenda sibi habitacula Romam praemisit" (cyt. wg S. Zakrzewskieg o, Opactwo.., s. 20-21) Warto podkreślić sceptycyzm autora, który rozeznawszy prawa wlasności gruntów na awentyńskim wzgórzu pyta: „gdzie tu szukać miejsca dla pałacu Ottona III?” (jw., s. 78). W sprawie nowych zapatrywań na tę rzecz zob.: A. Gi e y s z t o r, Rzymska studzienka..., s. 27, 29.

${ }^{20}$ Potępienie tego fałszerstwa znajdujemy w jednym $\mathrm{z}$ dokumentów z roku 1001 (zob. MGH Diplomata Ottonis III, s. 818 - 820 nr 389). Jeśli zaś darowizna Konstantyna stwierdzała, iż ,jest słuszną rzeczą aby tam święte prawa miały swoją siedzibę, gdzie Zbawiciel nasz, twórca świętych praw polecił świętemu Piotrowi zająć stolicę apostolstwa" (cyt. wg K. D o b r o w ols k i, Europa we wczesnym średniowieczu, Kraków 1923, s. 47, to środowisko ottońskie rewindykowało tylko te prawa i rolę Rzymu dla cesarza, co wyrażono już w Vita prior, a co również wyraziło się w przyjętej (od $1000 \mathrm{r}$.) tytulaturze (m. in. we wspomnianym dokumencie:) „Otto servus apostolorum et secundum voluntatem Dei Salvatoris Romanorum imperator augustus”, podkreślającej apostolskie i misyjne zadania i cele cesarza jako budowniczego civitas Dei. Warto też w tym miejscu zwrócić uwagę na mozaikę z triclinium lateraneńskiego, obok której Otton zapewne nie przeszedł obojętnie. Współczesna wprawdzie falsyfikatowi tzw. darowizny Konstantyna, jasno jednak ujmuje porządek wladzy ówczesnego świata, a jej deklaratywna dotąd treść w czasach Ottona III i Sylwestra II współbrzmiala z tworzoną przez nich rzeczywistością. Oto treść wyobrażeń tej kompozycji i jej inskrypcje. W eksedrze: Chrystus błogosławiący pośród apostołów; nas książce w jego ręku: PAX VOBIS; nas luku: GLORIA IN EXCELSIS DEO ET IN TERRA PAX HOMINI BONE VOLUNTATIS (Łuk. 2,14); u dołu: DOCETE OMNES GENTES BAPTIZANTES EOS IN NOMINE PATRI ET FILII ET SPIRITUS SANCTI ET ECCE EGO VOBISCUM OMNIBUS DIEBUS USQUE AD CONSUMATIONEM SECULI (Mat. 28, 19-20). Scena wyraża więc apostolską misję Kościoła, przelaną przez Chrystusa na jego uczniów. Ukonkretnieniem tej idei są dwie sceny po bokach na łuku eksedry. Z lewej: tronujący Chrystus przekazuje klucze klęczącemu św. Piotrowi, z prawej zaś św. Piotr, tronujący w białej tunice, wręcza klęczącym po bokach, więc przedstawionym egalitarnie, Karolowi Wielkiemu (nad głową: D[ominus] n[oster] CARULUS REX) i Leonowi III (nad glową: S[an]c[ti]ssimus D[ominus]n[oster] LEO P[a]PA) - atrybuty ich władzy; cesarz otrzymuje szkarłatną ozdobioną złotem chorągieq na włóczni jako vexillum. 
W takich to okolicznościach — jak wyżej przedstawiono - cesarz przedsiębierze pielgrzymkę ad limina martiris - do Gniezna. Coś z klimatu duchownego, w jakim się wówczas pogrążal, zachowały niektóre z przekazów pisanych. Zwłaszcza Thietmar w swym opisie gnieźnieńskiej podróży Ottona położył akcent na dewocyjny, pątniczy jej charakter. Kronikarz świadczy, że cesarz dowiedziawszy się o śmierci Wojciecha „wzniósł z pokorą hymn dziękczynny do Boga, iż w t y m cza si e [podkr. moje] przez palmę męczeństwa takiego z y s kał so bie słu gę [pośrednika]”. „Następnie cesarz dowiedziawszy się o cudach, które Bóg zdziałał przez upodobanego sobie męczennika Wojciecha wyruszył tam pospiesznie gwoli modlitwy" 21 . Wiemy, że pośród zimy ruszył z Rawenny przez Alpy i Bawarię do Polski. Wreszcie „gdy ujrzal z daleka upragniony gród [Gniezno], zbliżył się doń boso, ze słowami modlitwy na ustach. Tamtejszy biskup Unger przyjął go z wielkim szacunkiem i wprowadził do kościoła, gdzie cesarz zalany łzami prosił świętego męczennika o wstawiennictwo by mógł dostąpić łaski Chrystusowej"22. Opisujący zaś te zdarzenia z perspektywy około wieku Anonim Gall uważa „za godne przekazania pamięci” i to, że Otto „przybył do [grobu] św. Wojciecha dla modlitwy i poje d n a ni a [podkr. moje], a zarazem w celu poznania sławnego Bolesława, jak można o tym dokładnie wyczytać w księdze o męczeństwie [tego] świętego"23. Wydaje się, że

triumphale, papież zaś paliusz. U dołu tej sceny inskrypcja: BEATE PETRE DONAS VITAM LEONI P[A]P[AE] ET VICTORIAM CARULI REGI DONAS. Mozaika ta niegdyś w reprezentacyjnej auli starego pałacu lateraneńskiego, po jego zburzeniu za papieża Sylwestra V pozostała w zachowanej z dawnej budowli absydzie przyległej do tzw. dziś Scala santa, pełniącej w średniowieczu funkcję papieskiej kaplicy w ramach byłej rezydencji - i jest widoczna $z$ ulicy. Restaurowana dwukrotnie w czasach nowoży tnych nie utraciła jednak nic z zasadniczej treści swych wyobrażeń, jak to wynika $\mathrm{z}$ porównania $\mathrm{z}$ zachowanymi jej rysunkami humanisty Onofrio Panvinio (+ 1568); zob. Bibliotheca Apostolica Vaticana: Codex Barberinus Lat. 27 38; G. M a th i a e, Musaici medievale delle chiese di Roma, Roma 1967, s. 225.

${ }^{21}$ Kronika Thietmara, s. 182,200. Odnośne fragmenty w oryginale brzmią: „Imperator autem Rome certus de hac re effectus, condignas Deo supplex retulit odas, quod suis temporibus talem sibi per palmam artiris assumpsit famulum (jw., s. 183); „Postea cesar auditis mirabilibus, quae per dilectum sibi martyrem Deus fecit Aethelbertum, orationis gratia eo pergere festinavit" (jw., s. 203)

${ }^{22}$ Kronika Thietmara, s. 202, 204, odnośny zaś fragment w oryginale brzmi: „Videns a longe urbem desideratam nudis pedibus suppliciter advenit et ab episcopo eiusdem Ungero venerabiliter susceptus aeclesiam introducitur, et ad Christi gratiam sibi inpetrandam martyris Christi intercessio profusis lacrimis invitatur" (jw., s. 205-207).

${ }_{23}$ A n onim tzw. Gall, Kronika polska, przełożył R. G rod e cki, przekład przejrzał, wstępem i przypisami opatrzym M. Ple zi a, Wrocław 1965, s. $20-21$ (dalej cytuję: G all, Kronika). Fragment ten w oryginale: „Otto [...] ad sanctum Adalbertum orationis ac reconciliationis gratia simulque gloriasi Boleslai cognoscendi famam intravit”; - por. Galli Anonymi Cronicae et gesta ducum sive principum Polonorum, edidit, prefatione notisque instruxit Carolus Maleczyński, MPH series nova, t. II, Cracoviae 1950, s. 18 (dalej cytuję: Galli Cronicae). Roman Grodecki, jedyny dotychczas tlumacz na język polski Kroniki Galla, uzupełnił tekst po słowach „dla modlitwy i pojednania" (orationis et reconciliationis gratia) dodając wyraz: [z Bogiem]; por. wydanie tegoż, Kraków 1923 s. 72. Marian Plezia, krytyczny wydawca i redaktor kolejnych edycji powyższego przekładu Kroniki, opuścił wyraz [z Bogiem], dodając uwagę w komentarzu do tego miejsca: „Nie wiemy, co kronikarz chciał wyrazić słowami: i pojednania „( G all, Kronika, s. 21). Natomiast S. Tr a w k ow s k i (Pielgrzymka Ottona III do Gniezna. Ze studiów nad dewocja wczesnośredniowieczną, [w:] Polska w świecie. Szkice z dziejów kultury polskiej, Warszawa 1972, s. 119) twierdzi, że „nie mogła to być w żadnym razie pielgrzymka pokutna”. Na temat owej księgi „de passione martysis", na którą powołuje się Gall, zob. W. K ę tr z y ńs ki : Najdawniejsze żywoty św. Wojciecha..., 


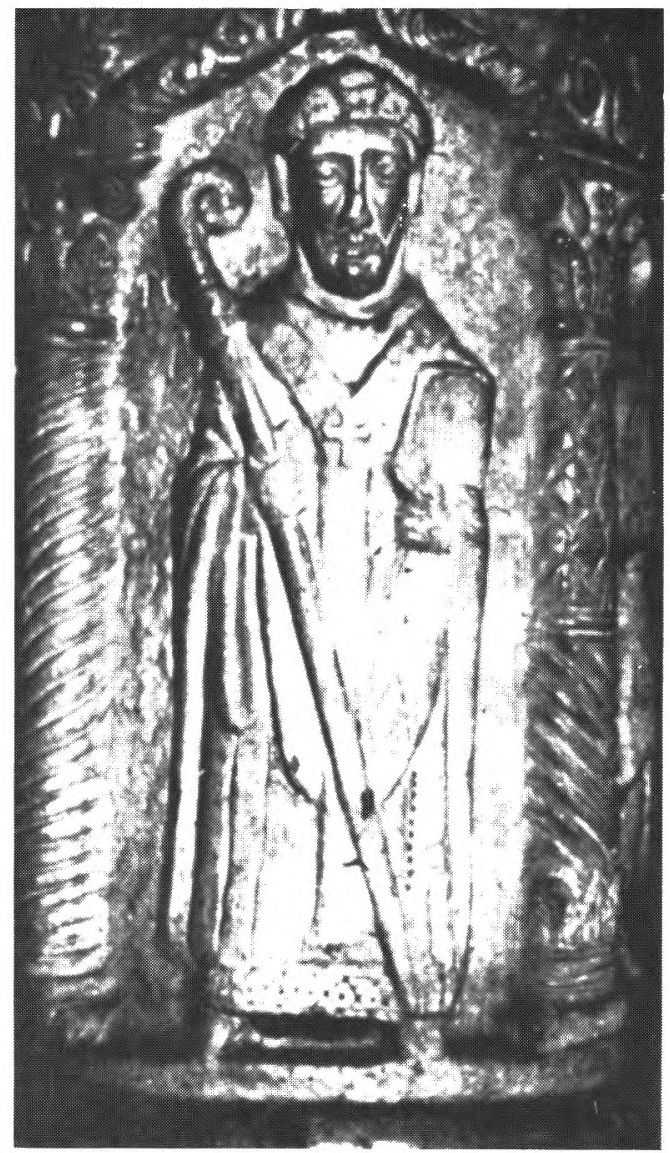

1. Postać biskupa in pontificalibus - domniemane wyobrażenie św. Wojciecha na studzience z Wyspy Tybrowej (ok. 100 r.)

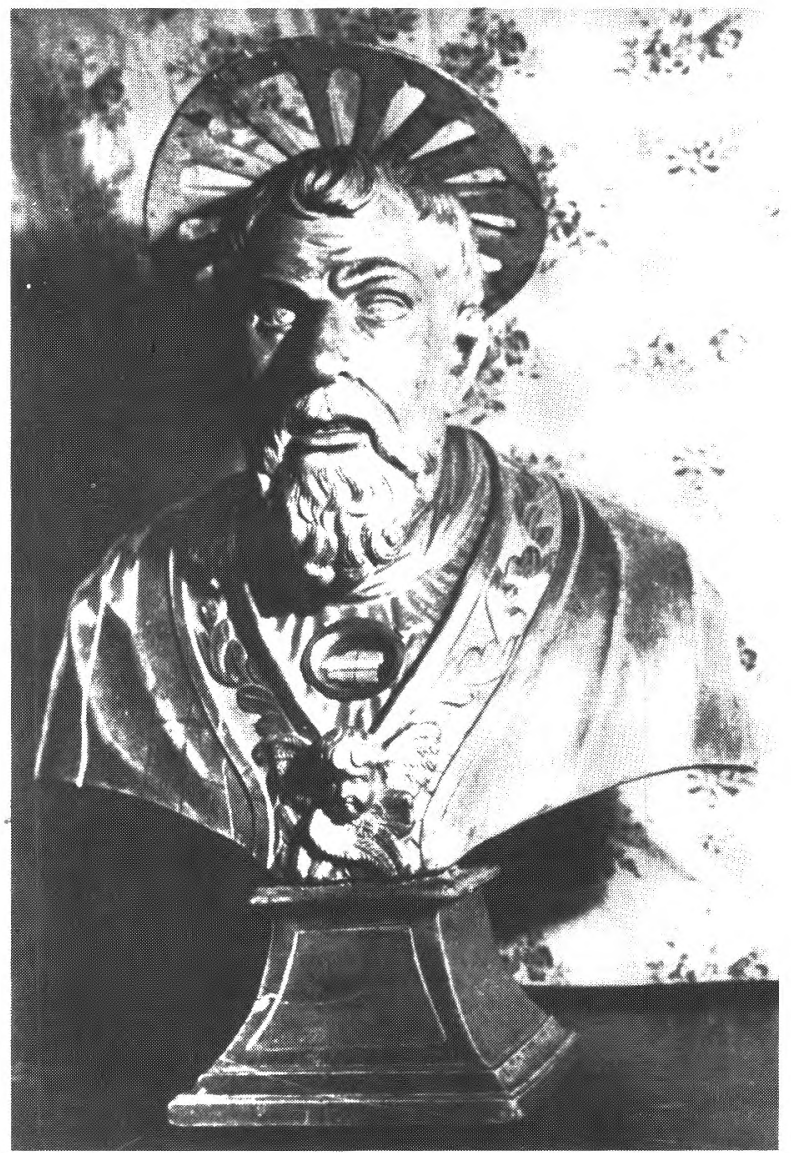

2. Drewniane popiersie św. Wojciecha (XVIII w.), zawierające cząstkę jego relikwi, demonstrowane dorocznie w bazylice na wyspie 23 kwietnia. 


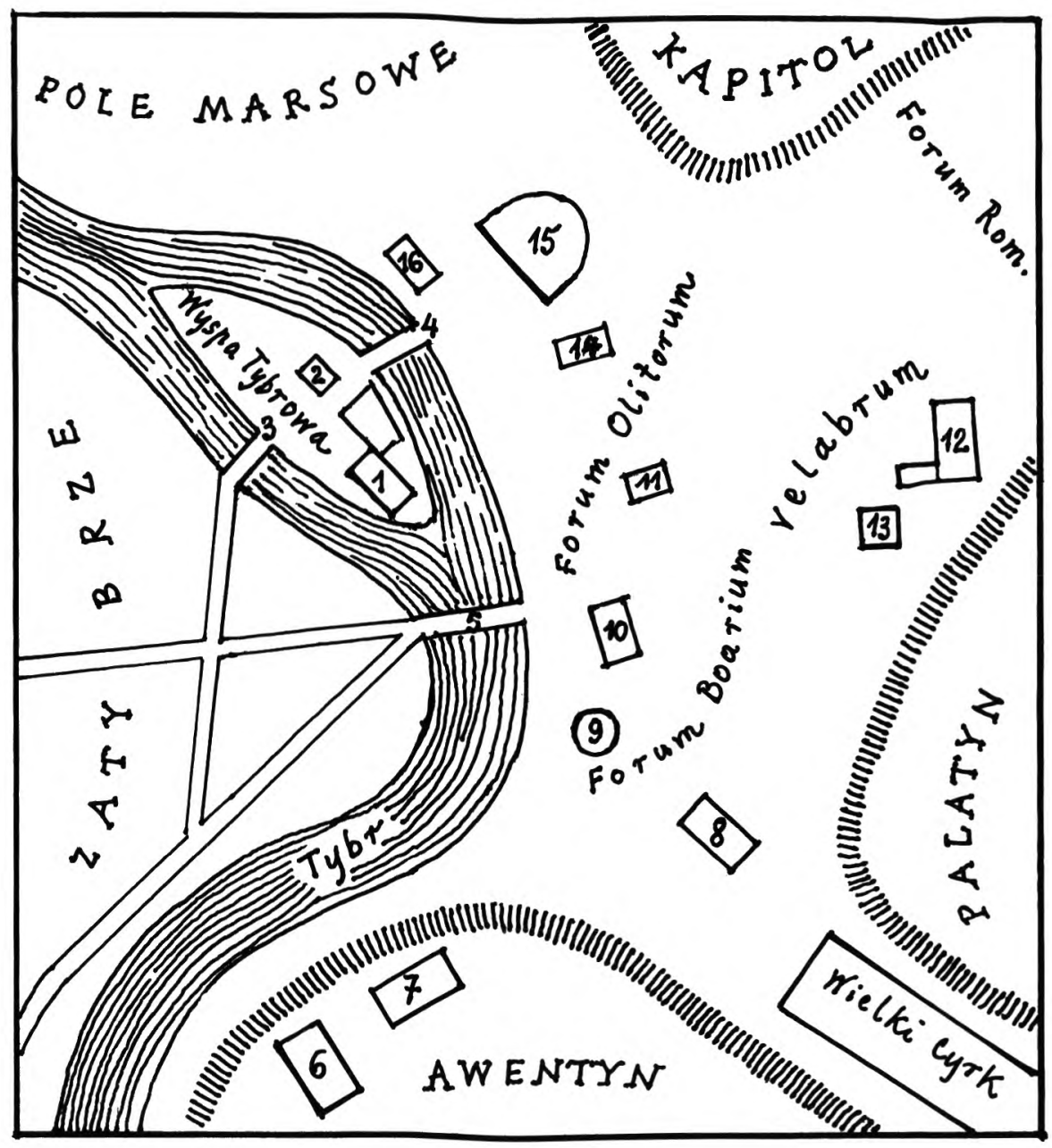

SZKIC SYTUACYJNY TYBROWEJ WYSPY I OKOLICY.

1. Ottońska bazylika św. Wojciecha (od XII w. Baz. S. Bartolomeo).2. Kościół św. Jana Kalibity (Chiesa di San. Giowanni Calibita). 3. Most Cestiusza (Ponte Cestio albo San. Bartolomeo). 4. Most Fabrycjusza (Ponte Fabricio albo... dei quattro capi albo... degli Ebrei). 5. Most Aemiliusza (Ponte Aemilio w XVI w. zerwany stąd tzw. Ponte Rotto). 6. Opactwo św. Aleksego i Bonifacego. 7. Bazylika św. Sabiny (Baz. di S. Sabina). 8. Kościół greckich emigrantów ze Wschodu: Bazylika Santa Maria in Cosmedin. 9. Swiątynia Herkulesa Zwycięskiego albo Oliwariusa. 10. Swiątynia Portunusa zwana też Fortunae Virilis, od IX w. kościół św. Marii Egipcjanki. 11. Dom Krescencjusza (Casa di Crescenci). 12. Bazylika św. Jerzego na Velabrum (San. Giorgio in Velabro) z przylegającym do niej Łukiem Bankierów (Arco degli Argentari). 13. Łuk Janusa Kwadrifronsa (Arco di Giano Quadrifronte). 14. Kościół św. Mikołaja w więzieniu (Chiesa di San. Nicolo in Carcere). 15. Teatr Marcellusa (Teatro di Marcello). 16. Synagoga (na terenie getta). 
w kontekście powyższych fragmentów z Thietmara i po uprzednim rozważeniu wypadków rzymskich z roku 998 jesteśmy teraz bliżsi rozumienia sensu tej zagadkowej Gallowej „reconciliatio” — pojednania, dla którego cesarz przybył do Gniezna.

Reconciliatio według prawa kanonicznego (w czasie późniejszym) znaczy przywrócenie do ponownej świętości po dokonaniu znieważenia. Za zniewagę można uznać zbezczeszczenie zwłok męża Bożego przez Prusów. Ale ta interpretacja słabnie wobec uprzedniego faktu uznania Wojciecha świętym, chyba że ową reconciliatio należałoby rozumieć również jako elevatio reliquiarum na ołtarz, która - jak wiemy — właśnie w obecności Ottona nastąpiła. Sama zaś pielgrzymka do grobu św. Wojciecha jako akt pietyzmu cesarza dla przyjaciela wiele przydawała splendoru kultowi męczennika. Ową reconciliatio w wymiarze religijnym, a realizowaną poprzez dewocyjny akt pielgrzymki i cały jej ethos, dyktowała jednak sytuacja. To Wojciech raczej miał tu wystąpić jako reconciliator, czyli ten, który przywraca zgodę, pojednawca, pośrednik, odnowic̀iè. Wreszcie reconciliatio (wg A. Jugana) ma też odcień znaczeniowy poenitentium (w sensie pojednanie). Otto, jak widać u Thietmara, zbliżał się ad limina martiris, do Gniezna boso, z pokorną modlitwą przebłagania, we łzach, z wolą zadośćuczynienia, więc z żalem i skruchą jako pokutnik. Trudno oprzeć się wrażeniu, że działał tu w tym samym duchu ekspiacyjno-pokutno-pojednawczym, z którego uprzednio już wyrosły przybytki ku czci św. Wojciecha na terenie Kampanii rzymskiej.

Wreszcie na aurę duchową Ottońskiej podróży do Gniezna wskazuje przyjęta na czas jej trwania tytulatura: „Otto tertius servus Iesu Christi et Romanorum Imperator Augustus secundum voluntatem Dei Salvatoris nostrique liberatoris". Zastąpiła ona stosowaną przeważnie dotychczas prostszą formułę: „Otto divina favente clementia rex”, a od maja roku 996: „[...] Romanorum Imperator Augustus" lub ,[...] Dei gratia imperator Augustus”24. Przyjęty na czas pielgrzymki tytuł można czytać na różny sposób, można odczuć w nim brzemię władzy, jakiego młodociany cesarz doznał zwłaszcza po roku 998, ale też podkreślał on związek osoby cersarza z Chrystusem oraz iunctim władzy (imperium) z funkcjami apostolskimi w osobie i działaniach cesarza. A to już jest element programu renovatio imperii. Bo też Ottońska podróż do Gniezna była ważnym elementem tego programu, jego dojrzewania i zarazem jego realizacji. W mistycznej aurze całej podróży gnieźnieńskiej, w trakcie której myśl cesarza krążyła wokół św. Wojciecha (a później też wokół Karola Wielkiego), dojrzewała Ottońska koncepcja nowego świata; „Wojciech, już jako święty

s. $25-26,39-41 ; \mathrm{S}$. Kęt rzyński, O zaginionym żywocie św. Wojciecha, Kraków 1902; M. Plezi a, Najstarszy zabytek historiografii polskiej. Zaginiony żywot św. Wojciecha, „Przegląd Historyczny" 43:1952 s. $562-570$.

${ }^{24}$ MGH Diplomata Ottonis III: zob. tytulaturę w dokumentach nr $344-366$ na s. $774-802$ i tamże tytulaturę w dokumentach nr $1-343$. 
męczennik, uczestnik sił nadprzyrodzonych, miał zostać osobistym patronem cesarza i cesarstwa, stać się symbolem ideologii ottońskiej"25. Rychła propaganda tego kultu w Europie, z rozmachem $\mathrm{z}$ inspiracji cesarza prowadzona, przemawia na rzecz takiej interpretacji. Przybytki kultu św. Wojciecha w Italii i za Alpami miały teraz być niby kolumny, na których by się wspierały luki ottońskiej budowy mającej objąć Europę.

A więc przybycie Ottona do Gniezna nie było zwykłym cesarskim nawiedzeniem świątyni, nie było też tylko aktem pietyzmu wobec przyjaciela. W każdym razie to wszystko nie jest wystarczającym wytłumaczeniem przedsięwzięcia podróży. Samo tylko wykonanie decyzji synodu rzymskiego w sprawie polskiej przez zainstalowanie Radzima-Gaudentego na arcybiskupstwie gnieźnieńskim, teraz de facto kreowanym, ani też organizacyjne urządzenie tego arcybiskupstwa - nie wymagałoby osobistego udziału cesarza, gdyby pod osłoną aktu dewocyjnego nie kryły się sprawy polityczne donioślejszego znaczenia. Należy przypomnieć rolę Bolesława Chrobrego jako najpierwszego animatora kultu św. Wojciecha. On to „na wagę złota” wykupił ciało męczennika od Prusów, był fundtorem kościoła metropolitalnego, gdzie spoczęły relikwie, miał wreszcie decydujący głos w istotnej sprawie ich dystrybucji. Celem podróży gnieźnieńskiej, postawionym przez Galla na równi z motywem dewocyjnym, było „poznanie sławnego Bolesława”. W Gnieźnie został zawarty układ. Gall, który w tym miejscu swej Kroniki streszcza zaginiony dziś dla nas Żywot św. Wojciecha, już tylko wspomina ową „pactio”, której postanowienia „papa Sylvester sancte Romane ecclesie privilegio confirmavit”26. Porozumienie to, które niewątpliwie definiowało miejsce Chrobrowskiej Polski i rolę samego Bolesława w imperium ottońskim, wyrażało się też $\mathrm{m}$. in. w trzech opisanych przez Galla symbolicznych gestach gnieźnieńskich. Było to ozdobienie przez Ottona skroni Bolesława diademem cesarskim, wręczenie mu włóczni św. Maurycego, „pro quibus illi [Ottoni] Boleslaus sancti Adalberti brachium redonavit" 27 .

Z interpretacją tych gestów i słów przez Galla przytoczonych różnie radziła sobie dotychczasowa literatura, bujnie narastająca wokół zjazdu gnieźnieńskiego. Nie mamy wszakże szczególniejszych powodów tu się nad tym zatrzymywać ${ }^{28}$. Skoro dwa pierwsze zwykle odczytywano lącznie w ich wzajemnej

${ }^{25}$ S. Trawk ow ski, Pielgrzymka..., s. 123. Opinię tę podzielają: P. E. S ch r a m m, Kaiser, Rom und Renovatio, t. 1, Darmstadt 1957, s. 137 - 140; A. G i e y s z t or, Sanctus et gloriosissmus martyr Christi Adalbertus, [w:] La conversione al cristianessimo nell'Europa dell'alto medioevo, Spoletto 1967; S. Traw kowski, In Polonia apud reverendum Beati Martyris Adalberti Sepulcrum. Ze studiów nad dewocja średniowiecza, [w:] Cultus et cognitio. Studia z dziejów średniowiecznej kultury, Warszawa 1976, s. $579 \mathrm{nn}$.

${ }_{26} \mathrm{G}$ alli Cronicae, s. 20; por. Gall, Kronika, s. 22. Zob. też: Z. Kozlowsk a-B udk owa, Repertorium dokumentów..., s. 5-6 (nr 4).

27 Galli Cronicae, s. 19; por. Gall, Kronika, s. $21-22$.,

${ }^{28}$ Dawniejsze opracowania (do r. 1950) na temat zjazdu gnieźnieńskiego, uwzględniające również hipotezę o patrycjacie dla Chrobrego, cytuje i omawia M. Z. Jedlicki w komentarzu do Kroniki Thietmara (s. $201-208,262-268$ ). Nadto należy wymienić: P. Bog da nowicz, Zjazd 
korespondencji, trzeci (gest rewanżu) jakby trochę umykał całościowej refleksji. Ramię św. Wojciecha - już sam wybór takiej partykuły, mimo całej wieloznaczność wszelkich symboli, ma znamię wymownie symboliczne. Z pewnością nie był to zwykły dar przyjaźni należący do obyczaju dyplomatycznego epoki. „Brachium Adalberti” wyrażało tu polityczne i ideowe wsparcie Bolesława dla poczynań cesarza ${ }^{29}$. Gall milczy o dalszych losach tej relikwii, choć znał je dobrze ze wzmiankowanej „księgi o męczeństwie”. Thietmar, który wiedział o wszystkich tych sprawach, też o nich nie pisze, za to na zakończenie swej relacji o zjeździe dodaje, że cesarz ,ufundował tam [tzn. w Gnieźnie] ołtarz i złożył na nim święte relikwie". Nastąpiło więc podniesienie relikwi, połączone z kolejną cesarską fundacją ku czci Wojciecha ${ }^{30}$. Zapewne też katedra gnieźnieńska otrzymała wówczas jeden z przynajmniej dwóch przepisanych w Rzymie i zabranych w drogę kodeksów z Żywotem św. Wojciecha; drugi mógł zostać ofiarowany kościołowi ku czci tegoż świętego w Akwizgranie ${ }^{31}$. Akwizgran stara stolica karolińskiego imperium, był drugim po Gnieźnie ważnym etapem podróży. Nastąpiły tu pamiętne wydarzenia: otwarcie grobu Karola Wielkiego, tym samym odnowienie jego pamięci; również tutaj cesarz ufundował kościół i klasztor żeński pod wezwaniem św. Wojciecha (i Hermesa). O pierwszym wydarzeniu wżmiankuje Thietmar i Rocznik kwedlinburski, a o obu - Kronika Ademara de Chabannes ${ }^{32}$.

Bez względu na to, czy ma słuszność S. Kętrzyński, upatrując w interpolacji tekstu C Kroniki Ademara „zbałamucony” relikt owego zaginionego Żywota $s ́ w$. Wojciecha w jego gnieźnieńskiej przez Brunona, z inspiracji Chrobrego,

gnieźnieńskiej w roku 1000, „Nasza Przeszłość” 16:1962 s. 5 nn; T. W a silew s ki, Bizantyńska symbolika zjazdu gnieźnieńskiego $i$ jej prawnopolityczna wymowa, "Przegląd Historyczny” 57:1966 s. $1 \mathrm{nn}$; B. Now a cki, Symbolika prawna w ceremoniale zjazdów monarchów polskich z wtadcami niemieckimi od X do potowy XII wieku, ,Roczniki Historyczne” 43:1977 s. $1 \mathrm{nn}$; M. Ro k os z, Wawelska wtócznia Bolestawa Chrobrego. Przeglad problematyki, „Rocznik Krakowski” 55 : 1989 s. 17 - 44, (w druku).

29 Zob. B. Now a cki, Symbolika prawna..., s. 15-17; R. Michalowski, Przyjaźń i dar w społeczeństwie karolińskim w świetle translacji relikwii, „Studia Źródłoznawcze” 28:1983 s. $1 \mathrm{nn}$.

${ }^{30}$ Zob. Z. S wi e ch ow ski, Ottońska konfesja katedry gnieźnieńskiej, „Studia Źródłoznawcze" 14:1969 s. $1 \mathrm{nn}$. Na ufundowanym przez siebie ołtarzu cesarz złożył - jak się przypuszcza szereg innych darów; zob. P. Sku biszewski, Tzw. kielich św. Wojciecha - pamiqtkq zjazdu gnieźnieńskiego?, [w:] Cultus et cognitio..., s. $523 \mathrm{nn}$.

31 Zob. J. Ka rwas ińs k a, Studia nad Żywotami, 2:1958 s. 42,51; tamże, 4:1959, s. 27.

${ }^{32}$ Zob. Kronika Thietmara, s. $208-211$. S. Kęt trzy ń s k i $(O$ zaginionym żywocie..., s. $48-$ 50) przytacza tekst interpolacji przekazu C Kroniki A de ma ra, gdzie m. in. jest taki fragment: „Solium eius [Caroli Magni] aureum imperator Oto direxit regi Bolisclauo pro reliquiis sancti Adalberti martiris. Rex autem Bolisclaus, accepto dono, missit imperatori brachium de corpore eiusdem sancti, et imperator gaudens illut excepit, et in honore sancti Adalberti martiris Basilicam Aquisgrani construxit miraficam et ancillarum Dei congregationem ibi disposuit. Aliud quoque monasterium Rome construxit in honore ipsius martiris". Na temat wynikających z powyższego źródła domniemań o osobistej obecności Bolesława Chrobrego w Akwizgranie oraz o symbolicznej wymowie darowanego mu wówczas przez Ottona „złotego tronu” Karola, aż po tyle frapujące, co nie ugruntowane źródłowo hipotezy o układzie sukcesyjnym Ottona z Chrobrym zob.: S. Kętrzyński, Karol Wielki $i$ Bolestaw Chrobry, „Przegląd Historyczny” 36 : 1946 s. 19 - 25; Z. Wo j ci e ch ow s ki, Bolestaw Chrobry i rok 1000, [w:] tegoż, Studia historyczne, Warszawa 1955, s. $78 \mathrm{nn}$; tenże, Patrycjat Bolestawa Chrobrego, tamże, s. $104 \mathrm{nn}$; P. Bog da n ow icz, Zjazd gnieźnieński. 
dokonanej redakcji - dla nas istotna jest zawarta tutaj wiadomość, iż cesarz $\mathrm{z}$ radością przyjąwszy od Bolesława ramię św. Wojciecha i ufundowawszy ku jego czci kościół w Akwizgranie ,aliud quoque monasterium Romae construxit in honore ipsius martiris". Tak więc część otrzymanych w Gnieźnie relikwii zostawił Otton w Akwizgranie, resztę przywiózł do Rzymu, gdzie - jak powiada Thietmar - „przyjęty został $\mathrm{z}$ wielką chwałą przez papieża i jego biskupów”33, a „przez Kwirytów [tzn. Rzymian] — według Żywota pięciu braci-z nieszczerą radością, lecz bardzo szumnie"34. Ślad przeniesienia Wojciechowych relikwii do Rzymu zachował też powstały w Niemczech około 1002 roku najstarszy hymn ku czci Adalberta ${ }^{35}$.

Pochodzącą z 2. połowy XI wieku ogólnikową informacją o rzymskiej fundacji cesarza ku czci św. Wojciecha, zawartą w interpolacji tekstu C Kroniki Ademara, rozjaśnia pochodząca najpewniej z początku XI wieku wiadomość na ten temat w tekście Translatio reliquiarum ss. Abundii et Abundantii ${ }^{36}$. Fakt przeniesienia Wojciechowych relikwii do Rzymu potwierdzają inne, późniejsze pomniki. Należy do nich Chronica Polonorum z przełomu XIII i XIV wie$\mathrm{ku}^{37}$, dalej - skompilowana u schyłku XIV wieku Chronica principum Poloniae, która na zakończenie relacji o zjeździe gnieźnieńskim wspomina o rzymskim przeznaczeniu Wojciechowej partykuły ${ }^{38}$. Wreszcie warmiński, z przełomu XIV i XV wieku odpis Miraculorum s. Adalberti (powstałych jednak pod

${ }^{33}$ Kronika Thietmara s. 210.

34 Zob.: Piśmiennictwo..., s. 167. Powrót więc był równie jak wyjazd uroczysty: „Nigdy jeszcze cesarz nie wyjeżdżal [...] z większym przepychem" (Kronika Thietmara s. 202). Mimo tego zgodnie podkreślanego splendoru wyprawy gnieźnieńskiej, oczywisty jest dla nas także element pielgrzymki pokutno-ekspiacyjnej. Ponadto wyprawa gnieźnieńska znaczyła zarazem rozszerzenie horyzontu geograficzno-politycznego na obszar nietknięty nigdy dotąd stopą rzymską, z czego zapewne elita ottońskiego renesanst zdawala sobie sprawę. Reminiscencją tego jest zanotowana przez Thankmara (Vita Bernvardi, c. 25) mowa, jaką cesarz miał wygłosić do zbuntowanych Rzymian: „Vos in remotas partes nostri imperii adduxi, quo patres vestri, cum orbem ditione premerent, numquam pedem posuerent" (cytuję za: S. Tr aw k ow ski, Pielgrzymka..., s. 118).

35 „Romanis retulerat brachii munera” (Cantica medii aevi polono-latina. t. 1: Sequentiae, ed. H. Kowalewicz, Warszawa 1961, s. 13); J. K a r w a s i ń s k a, Studia nad Żywotami, 2:1958 s. 51.

36 Najstarsze zachowane rękopisy tekstu Translatio reliquiarum ss. Abundii et Abundantii pochodzą dopiero z XV wieku. Pierwsi drukowali go jezuici ,apud Fr. Zanettum” w 1584 roku. Interesujący nas fragment przytacza C. B a r o n i u s z w swych Annales Ecclesiastici (t. 11, Moguntiae 1606, s. 400 - 401). Z kolei obszerny fragment Translatio wydali bollandyści w Acta Sanctorum (September, t. 5, Bruxellis 1857, s. 303 - 306). Wreszcie tekst wydał A. Kolberger w: „Zeitschrift für die Geschichte und Altertumskunde Ermlands" 7:1879-1880 s. 517 - 518). Poszczególne z przykładowo podanych wydań, oparte o różne odpisy różnią się między sobą. S. K ę tr z y ńs ki (O zaginionym Żywocie..., s. 45) spisanie Translatio lokuje ,poza początkiem XII wieku”. A. Gie y s z t or (Rzymska studzienka..., s. 22) uważa ją za „tekst hagiograficzny z XI w.” J. K a r w a si ńs k a (Studia nad Żywotami, 2:1958 s. 45) twierdzi, że powstał on „koło roku 1001”.

37 W królewieckim rękopisie Chronicae Polonorum zapisano, że z Gniezna „Otto imperator [...] Romam est reversus recepto brachio sancti Adalberti, quod locavit [in] Insula in ecclesia, ubi nunc sanctus Bartholomeus requiescit”. Wydawca zabytku (MPH t. III s. 618) L. Ćwikliński uważa ten fragment za interpolację, jednakże przytacza opinię S. Smolki (zob. tamże, s. 586), wedle której należy on do tekstu pierwotnego, lecz został wypuszczony z egzemplarza, z którego wypłynęły inne znane odpisy tego zabytku.

38 „Boleslaus [...] pro recompensa vero tradens Cesari brachium Sancti martyris Adalberti, quod testatur Martini Cronica; referens, illud per Ottonem tercium Romam delatum et positum in ecclesia sancti Bartholomei" (MPH t. III s. 439 - 440). 
koniec wieku XIII) przynosi ciekawą informację na ten temat ${ }^{39}$. Milczy o tym fakcie Długosz, za to sprawa znana była Marcinowi Kromerowi, zapewne wprost z rzymskiej tradycji ${ }^{40}$.

W niniejszym przeglądzie przekazów powagę najbliższego zdarzeniu zapisu zyskuje wspomniany już tekst Translatio reliquiarum ss. Abundii et Abundantii. Mimo zepsucia tekstu naleciałościami i przy braku dotychczas wnikliwej krytyki porównawczej wszystkich zachowanych odpisów, dodatkowo utrudniającym definitywne określenie czasu jego pierwszej redakcji, przeważa pogląd, że powstał on na początku wieku XI, a w każdym razie, by przytoczyć opinię J. Karwasińskiej, „wiarygodność jego danych w tym znaczeniu, że są one powtórzeniem pogłosek obiegających około 1001 roku, nie budzi wątpliwości"41. Oto czego dowiadujemy się z tej relacji. Naprzód krótko i bez rewelacji streszcza ona żywot i misję św. Wojciecha, który zapragnąwszy posiąść palmę męczeństwa „udał się do innego [niż ten, z którego pochodził] kraju słowiańskiego gdzie byli pogańscy pobratymcy aby ich przywieść do wiary w Chrystusa i aby porzuciwszy swe błędy, Boga żywego, który jest w niebie uczcili i wyznawali. Ponieważ ci [poganie] słuchać jego nie chcieli, zabili go i tak dobry pasterz przez palmę męczeństwa odszedł od Pana". Następnie zabytek opowiada, jak cesarz zwany tu królem, usłyszawszy o śmierci Wojciecha uczcił jego pamięć: „,...] nie mogąc pogodzić się z żarliwym pragnieniem tak wielkiego męczeństwa [bliskiej sobie osoby], w orszaku rzymskich senatorów, biskupów i innych osób duchownych podążył na drugą stronę Alp, do Słowiańszczyzny, celem wywiezienia stamtąd do Rzymu relikwii świętego męczennika Wojciecha; który [jednak tylko] rękę jego zyskawszy, złotem i klejnotami zdumiewająco ją ozdobił, kościół jego imieniu [poświęcony] mi ę d zy dwo ma mos t a mi zbudował i z wielką czcią tam ofiarowal, a także pochodzenie, czyny i męczeństwo Wojciecha cudowną sztuką [w natchnieniu] ułożył i w książeczce spisując sporządził" 42 .

${ }^{39}$ W. Kętrzyński, wydawca tego zabytku (MPH t. IV s. 238 przyp. 1; por też s. 222) zauważa, że kodeks proweniencji warmińskiej natrafiony w bibliotece św. Marii w Gdańsku, zawiera tekst Miracula..., których kapista dodał oryginalne zakończenie. Czytamy w nim, jak cesarz obdarowany ramieniem św. Wojciecha ,gaudens Romam reversus. In predicta vero alma urbe in Insula Tyberina apud Sanctum Barholomeum reliquias predictas cum gloria et honore collocavit. Cuius partem brachii reverendus pater dominus Iohannes Striperok episcopus de speciali licencia vicarii domini Urbani papae quinti [1363 - 1370] ad ecclesiam suam Warmiensem cum veneratione reportavit, gracias agens Deo, suius regnum eternum est et imperium super omnes in seculo seculorum".

${ }_{40}$ M. K rome r, De origine et rebus gestis polonorum, Basileae 1555, s. 53: „Vicissim autem brahium divi Adalberti a novo rege [Boleslao] accepit, quod Romae in insula apud divi Bartholomei aedem ab eo postea depositum esse fertur". Później powtarza to jeszcze F. J a ros ze wisz: Matka świętych Polska albo żywoty świętych, błogosławionych, wielebnych, świqutobliwych Polaków i Polek, Kraków 1767 (lub Piekary 1850); zob. tam w czytaniu o Bolesławie Chrobrym na dzień 3 stycznia.

${ }^{41}$ J. K a rwas ińs k a, Studia nad Żywotami, 4:1959 s. 19.

42 Odnośny fragment w oryginale brzmi następująco: ,Adalbertus [...] desideravit ad palmam martirii venire. Abiit autem in aliam Sclavoniam, in qua erant gentiles, ut eos ad fidem Christi revocaret, et relicto eorum errore deum vivum, qui in Celis est, adorarent et colerent. Qui cum illum audire noluissent, interfecerunt eum et ita bonus pastor post palmam martirii migravit ad Domi- 
Przekaz ten jak widać, zdradza wszelkie cechy hagiograficznego zapisu potocznej, ogólnikowej i zwłaszcza w początkowej partii, dość bałamutnej opowieści. Jednak ignorować go nie można $\mathrm{m}$. in. dlatego, że opowiada o Wojciechu z odległej Słowiańszczyzny jako o osobie dobrze w Rzymie i Italii znanej oraz bliskiej cesarzowi, który okazał mu szczególną cześć. Argumentem za bliską roku 1000 datą powstania tekstu Translatio reliquiarum... wydaje się być użyta tam nazwa „Sclavonia” na określenie Polski Chrobrego, do której udał się Otton. Termin ten, (również w formie: Sclavania, Sclavenia, Sclavinia) jako określenie geograficzno-polityczne, dla czasów już nieco tylko późniejszych anachroniczny, około roku 1000 był właśnie używany, jak świadczy o tym $\mathrm{m}$. in. formuła loci w wystawionym w Gnieźnie (13 marca $1000 \mathrm{r}$.) Ottońskim dokumencie: ,actum in Sclavania in civitate Gnesni, ubi corpus beati martyris Adalberti requiescit”43. I wreszcie na podstawie uwagi, że Otto „in Sclavoniam pergit ad educendas Romam reliquias [...] Adalberti” i „manus eius auferens", nie można wykluczyć, że pierwotnym zamysłem cesarza było zabranie z Gniezna całego korpusu męczennika, na co Bolesław jako wykupiciel, świecki kustosz i dystrybutor relikwii był w prawie się nie zgodzić.

Powróćmy do miejsca złożenia przez cesarza relikwi (ramienia czy ręki?) św. Wojciecha. Jedynym w Rzymie miejscem ,inter duos pontes” jest Wyspa Tybrowa. Ta legendarna, opływowego ksztaltu, niewielka $(270 \times 70 \mathrm{~m})$, ujęta we dwa ramiona Tybru wysepka leży na wysokości Janiculum, wznoszącego się na prawym brzegu rzeki, oraz Awentynu, Palatynu i Kapitolu ze strony przeciwnej. Od czasów republikańskich wyspę ze stałymi brzegami łączą dwa mosty. $\mathrm{Z}$ miastem łączy ją Pons Fabricius, który zbudował w roku 62 przed Chr. - jak świadczy inskrypcja — „Quintus Fabricius curator viarum”. Potoczna jego nazwa: Ponte dei Quattro Capi, pochodzi od starożytnej, marmurowej hermy Ianusa Quadrifronsa, wmurowanej w kamienną balustradę; nazywa się go też czasem „mostem żydowskim” (Ponte degli Ebrei). Drugi, łączący wyspę z Zatybrzem, nazywa się Pons Cestius, gdyż skonstruował go pretor Gaiusz L. Cestiusz w 46 r. przed Chr.

Od głębokich czasów starożytnych Wyspa była miejscem kultu Jowisza, Fauna, a zwłaszcza Eskulapa, którego przybytek połączony z hospicjum ze względów sanitarnych ulokowano w tym izolowanym miejscu; stąd też wyspa czasem była zwana Insula Aesculapi lub Insula Serpentis Epidauris, a ze wzglę-

num. Quo audito, rex ardorem tanti non ferens martiris, cum senatu Romano et Episcopis et Clericis extra montes in Sclavoniam pergit ad educendas Romam reliquias beati martiris Adalberti. Qui manus eius auferens auro et gemmis mire exoravit et Ecclesiam nomini eius inter duos pontes fabricavit et magnea dignitati redidit, nec non ortum eius, actus et passionem mira arte composuit et in libello scribi fecit” („Zeitschrift für die Geschichte...”, s. 517).

${ }_{43}$ MGH Diplomata Ottonis III, s. 779 (nr 349). Wspomnijmy też „Sclavinie” w znanej miniaturze $\mathrm{z}$ ewangeliarza ottońskiego $\mathrm{z}$ roku ok. 1000 oraz interpretację tejże nazwy przez $\mathrm{P}$. S k u bi sze w s k i e go: W stużbie cesarza, w stużbie króla. Temat władzy w sztuce ottońskiej, [w:] Funkcja dzieta sztuki, Warszawa 1972, s. $35 \mathrm{nn}$. Zob. też: W. S w o b od a, Sklavinia, [w:] Stownik starożytności stowiańskich, t. 5, Wrocław 1975, s. 228. 
du na trwałość tradycji asklepiadejskich w tym miejscu do dziś (znajduje się tam szpital) Wyspę Tybrową nazywa się niekiedy L'Isola del Salute.

Przytybrzański obszar w okolicy wyspy między Kapitolem, Palatynem i Awentynem od czasów jeszcze republikańskich stanowił główny puls życia ekonomicznego Rzymu. Tu, wokoło rotundalnej świątyni Herkulesa Zwycięskiego lub Oliwariusa oraz na Velabrum, gdzie znajduje się łuk Ianusa Quadrifronsa i Bazylika San. Giorgio in Velabro, jak w starożytności, tak w średniowieczu istniały rynki. Pomiędzy skarpą awentyńską a Tybrem było emporium ze składami i magazynami towarów przywożonych barkami z Ostii. Tradycja handlowa tej okolicy żyła. Tutaj u schyłku X wieku, nieopodal świątyni Portunusa (bóstwa opiekuńczego portów rzymskich), przerobionego teraz na kościół Marii Egipcjanki, Mikołaj, syn Krescencjusza i Teodory - jak świadczy dochowana inskrypcja - zbudował sobie istniejący do dziś, sklecony z antycznych resztek, zdobny dom (casa dei Crescencio) i tutaj była jego komora celna na Tybrze. Obszar ten w interesującym nas okresie zamieszkiwał przeważnie przedsiębiorczy grecko-żydowski żywiol emigrantów ze Wschodu. Przecie i dziś naprzeciw wyspy stoi rzymska synagoga. A dokument ottoński z 996 roku nazywa ten brzeg ripa greca. Swiadectwem tej przewagi jest też $\mathrm{m}$. in. grecki kościół Santa Maria in Cosmedin. Grecy także w tym czasie nadali wyspie nazwę Lycaonia, ale też w X wieku na południowym cyplu wyspy, gdzie wznosiły się ruiny świątyni Eskulapa, żywa była pamięć jego kultu. Widać więc, Wyspa Tybrowa była miejscem w Rzymie niepoślednim. Jeszcze kardynał Baroniusz na przełomie XVI i XVII wieku określi ją jako „locum Urbi notissimum, suique antiquitate omnium rerum Romanorum Scriptorum memoria famosissimum" ${ }^{44}$. W tej znaczności miejsca, jaką wyróżniała się Tybrowa Wyspa w topografii stolicy świata, tkwi niewątpliwie powód ulokowania tu przybytku ku czci nowego patrona cesarstwa. Ale czy tylko?

Leżąca o rzut oka $\mathrm{z}$ beñedyktyńskiego Awentynu, jak i cesarskiego Palatynu, Wyspa Tybrowa była jak soczewka, w której skupiało się jakby Ottonowe spojrzenie z perspektywy cesarskiego pałacu oraz spojrzenie $\mathrm{z}$ awentyńskiego klasztoru. Zarówno cesarzowi, jak i mnichom od św. Bonifacego i Aleksego, gdy wspominali Wojciecha - sugeruje A. Gieysztor - Isola Tyberina mogła wówczas przywodzić na myśl ową „małą wysepkę, otoczoną wijącą się wokół rzeczką" 45 , którą pierwszemu żywotopisarzowi św. Wojciecha wspominał Ra-

${ }^{44}$ C. B a roniusz, Annales..., t. 11 s. 400. Obfite referencjje Wyspy Tybrowej dla czasów antycznych zob.: J. We is s, Tiberina insula, [w:] Paulys Real-Enzyclopädie der classischen Altertumswissenchaft. Zweite Reihe ( $\mathrm{R}-\mathrm{Z})$, Bd. 11, Stuttgart 1936, szp. 782 - 784; [ G all], Insula Lycaonia, tamże, Bd. 18, Strassburg 1916, szp. 1595. Ważniejszemonografie: M. B e s n i e r, L'Insula Tiberina dans l'antiquité, „Bibliothèque des Écoles Françaises d'Athènes et de Rome”, 87:1932; $\mathrm{H}$. W a g e $\mathrm{n}$ v o r $\mathrm{t}$, Isles of the Blessed and Insula Tiberina, [w:] tegoż, Studien in Roman literature, culture and religion, London 1956; M. G u a r d u c ci, L'Isola Tiberina e la sua tradizione ospitaliera, Roma 1971.

${ }_{45} S$ w. Wojciecha żywot pierwszy, [w:] Piśmiennictwo..., s. 79. Przy tej okazji A. Gi e y s z t or (Rzymska studzienka..., s. 22,27 i przypis 12), a za nim T. D u n in-Wą s ow icz (Wezwania św. 
dzim-Gaudenty, jako miejsce lądowania apostoła w Prusach i początek jego męczeństwa. Sw. Wojciech - jak wiemy - z klasztorem awentyńskim był osobiście związany. Tu dwukrotnie przebywal jako członek konwentu, a nawet prawdopodobnie pełnil przejściowo funkcję opata przed Janem Kanapariuszem, gdy opat Leon wraz z tymże Janem przebywał jako legat Jana XV w Galii dla rozsądzenia sporu między biskupem Reims Arnulfem a Gerbertem (przyszłym papieżem Sylwestrem II) ${ }^{46}$. Miał tu swoich przyjaciół i uczniów, na których wywarł piętno swej osobowości. Tu wreszcie spisano pierwszą redakcję jego Żywota, a później Żywot drugi. „Blask świętości męczennika - powiada W. Kętrzyński - rzucił swe promienie na klasztor, który go przytulił i na zakonników, wśród których żył czas dłuższy”. Poza tym jednak w klasztorze awentyńskim dominowały dwie równorzędne legendy hagiograficzne ku czci św. Bonifacego i św. Aleksego, które dostarczały konwentowi obfitego pokarmu duchowego. Na nowy kult trzeciego świętego nie było tu już jakby miej$\mathrm{sca}^{47}$, tym bardziej że głównemu animatorowi czci dla Słowianina, Ottonowi III, szło najwyraźniej o szeroki jego wymiar.

Na południowej części wyspy, na terenie należącym jeszcze do niedawna do ludzi z partii Krescencjusza, darowanym następnie opactwu, pośród ruin świątyni Eskulapa stała już kaplica Najświętszego Salwatora, a przy niej niewielki klasztorek (cela mnichów), będący filią awentyńskiego konwentu. I to miejsce zdało się cesarzowi najsposobniejsze do zaszczepienia w Rzymie kultu św. Wojciecha.

Wojciecha..., s. $31 \mathrm{nn}$ ) zauważyli, że niektóre inne ottońskie fundacje ku czci św. Wojciecha zostaly ulokowane na ostrowach; np. zbudowany przez biskupa Notgera kościól na wyspie Mozy w Leodium (zob. J. Ka rwas ińs k a, Studia nad Zywotami, 2:1958 s. 51 przypis 68, s. $55 \mathrm{nn}$ ) czy pustelnia św. Romualda w delcie Padu, gdzie „Otto [...] świętemu Wojciechowi [...] przepiękną zbudowal rotundę z marmurowymi kolumnami, a wydal na to dzieło sto funtów" (Zywot pięciu braci, [w:] Piśmiennictwo..., s. 174). Wydaje się, że początkowo kult św. Wojciecha, który popłynął z Gdańska wzdłuż wybrzeża Bałtyku, by nawracać i chrzcić Prusów, i zginął nieopodal brzegu, mógł się w większym niż dziś stopniu kojarzyć z wodą. S. Kęt r zy ńs ki ( $O$ zaginionym żywocie..., s. 37) zauważył pozornie drobny szczegół, związany ze śmiercią świętego, a rozłamujący tradycję o tym fakcie na dwie grupy przekazów. Jest to wiadomość o wrzuceniu ciała zamordowanego do pobliskiej wody (tak jest m. in. u Thietmara, w Passio S. Adalberti, w tekście C Kroniki Ademara). Wprawdzie dwa wielkie żywoty rzymskie tego szczególu nie notują, ale nie musi to oznaczać, że mnisi na Awentynie i cesarz nie znali tej tradycji. Wreszcie ugruntowanym w ikonografii atrybutem tego świętego, prócz szat pontyfikalnych i krzyża misyjnego, jest wiosło (jako narzędzie martyrium).

${ }_{46}$ Przypuszczenie to S. Zak r ze w s k i (Opactwo..., s. 39, 84 - 85) opiera na wiadomości zawartej w Miracula Sancti Alexii, które przechowując tradycję klasztorną awentyńskiego opactwa są cennym źródłem do jego dziejów na przełomie X i XI wieku; zob. Acta Sanctorum. Julius, t. 4, Antverpiae 1725, s. $26-262$.

${ }^{47} \mathrm{Na}$ temat początków legendy hagiograficznej ku czci św. Aleksego i wyrażonego w niej ideału życia kultywowanego w klasztorze awentyńskim zob.: W. S wo bod a, Aleksy św., [w:] Stownik starożytności stowiańskich, t. 7 cz. 2, Wroclaw 1986, s. 350-352; A. G i e y s z t o r, Dobrowolne ubóstwo, ucieczka od świata i średniowieczny kult św. Aleksego, [w:] Polska w świecie..., s. 21 nn. Gdy chodzi o św. Wojciecha, klasztor zadowolił się jakąś cząstką jego relikwii, a również odkryty tam przez ks. Warszawskiego przed 1956 rokiem fresk z wyobrażeniem św. Wojciecha ma pochodzić z tamtych czasów i może być świadectwem pobożnej o nim pamięci; o fresku tym wspomina W. Me y szt ow icz, Koronacje pierwszych Piastów [w:] Sacrumt Poloniae Millenium, t. 3, Rzym 1956, s. 33. 
Jeszcze w roku 986 Grzegorz tzw. Porticelleński z Kalabrii, członek konwentu awentyńskiego, „za radą” (ex consilio) cesarzowej Teofano, z którą późniejsza legenda skojarzyła go jako jej brata, „ecclesiam in honore S. Salvatoris construxit", gdzie ze swymi uczniami Maurem i Andrzejem przez kilka lat przebywal $^{48}$. Z kolei w roku 987 Jan, syn Dymitra — zdaniem Zakrzewskiego — bliski krewny Krescencjuszów, występujący pod zaszczytnym tytułem „eminentissimus et dux", uczynił na rzecz klasztoru św. Bonifacego i Aleksego szczodre nadanie, składające się $\mathrm{m}$. in. z Wyspy Tybrowej w całości wraz z prawem pożytkowania jej brzegów w celach rybołóstwa w Tybrze i wraz z owym kościołem Zbawiciela, przy którym już była cela mnichów od św. Boniface$\mathrm{go}^{49}$. Że zaś nadanie to pochodziło $\mathrm{z}$ rodzinnego majątku Jana, świadczy fakt, iż odnośny dokument wystawił on wraz ze swymi siostrami i przy konsensie ich mężów. Akt ten był już ostatecznym zakończeniem dłużej trwających sporów o prawa własności wyspy. Został on potwierdzony przywilejem generalnym Ottona III dla klasztoru awentyńskiego z dnia 31 maja 996 roku, co zarazem wyjaśnia nam dotychczasowe zawikłania tej sprawy ${ }^{50}$.

Tak więc przybytek ku czci św. Wojciecha w Rzymie zaistniał na gruncie będącym w posiadaniu awentyńskich benedyktynów. Istniejący tu już kościół Najświętszego Salwatora był miejscem, w którym złożono Wojciechowe relikwie, w ślad za czym poszło i nowe wezwanie. W epoce romańskiej często tak bywało, że na pierwotne wezwanie, przeważnie Najświętszego Salwatora lub Bogurodzicy, nakładały się nowe tytuły kościoła w postaci imion świętych patronów; przykładem mogą służyć pojawiające się kolejno dedykacje katedry wawelskiej: Najświętszego Salwatora i św. Wacława, a dopiero od 1254 roku

48 Zob.: De Sancto Gregorio abbato Porcetensi, [w:] Acta Sanctorum November, t. 2 pars I, s. 462,472 ; S. Zakrzew s ki, Opactwo..., s. 21. Byl to dość powszechny w Rymie już od wieków obyczaj, że wiele antycznych ruin, od których z zabobonnym przestrachem stroniło często osadnictwo, odbudowywały wspólnoty zakonne, przekształcając je w przybytki kultu chrześcijańskiego. Był wskazać na San Nicolo i nCarcere, Santa Maria in Cosmedin (VI w.), San Giorgio in Velabro (VII w.), zbudowane na starożytnych ruinach, lub pogańską świątynię Portunusa zamienioną w IX w. na kościół św. Marii Egipcjanki - jako na przykłady z najbliższego sąsiedztwa wyspy. Zresztą sama wyspa, zwana przez Greków Lykaonią, już wcześniej łudziła swym odosobnieniem mnichów pochodzenia greckiego szukających ucieczki od zgiełku miejskiego. Pod koniec X wieku stał tu już (istniejący do dziś w zbarokizowanej formie) kościółek poświęcony św. Janowi Kalibicie. Utrzymujący z Awentynem kontakty św. Nil i jego uczniowie, do których należał też Grzegorz Porticelleński, byli jego gorliwymi wyznawcami; zob. S. Zak rzews ki, Opactwo..., s. 60, 82; A. Gi e ys z t or, Dobrowolne ubóstwo..., s. $21 \mathrm{nn}$.

${ }^{49}$ "Concedimus vobis insula una in integrum, cum Ecclesia infra se ad honorem Salvatoris Domini nostri Hiesu Christi, et cellas, vel omnia infra se habentes, sicuti a fluminibus circumdata esse videtur cum piscarie tres, quae sunt lecticarie in ipsis fluminibus posite, una vero, que vocatur de Pecomaro, alia de Andreas Monachus dicitur, tertia de Merngario vocatur, introitu namque et exitu suo, et licentiam habeas, vestros piscatores piscare ubicumque voluerint" (cytuję za: F. N e ri $\mathrm{n}$ i, De templo et coenobio sanctorum Bonifacii et Alexii, Romae MDCCLII, s. 379-380).

50 Zob. MGH Diplomata Ottonis III, s. 620-621 (nr 209). Dokument mówi, że już opat Leon przedkładał Ottonowi II, więc przed rokiem 983, tytuly prawne do wyspy. W roku 986 osiadl tu i zbudowal klasztorek filialny Awentynu Grzegorz Porticelleński. Tymczasem, jak wynika z cytowanego wyżej dokumentu (przypis 49), jeszcze w roku 987 książę Jan calą wyspę uważał za swoją własność, kiedy zrzekł się jej na rzecz benedyktynów. Dokument zaś generalny cesarski zatwierdzil im wyspę ostatecznie. 
również św. Stanisława biskupa i męczennika. Jedyną dziś pamiątką pịerwotnego tytułu bazyliki na wyspie jest wyobrażenie Zbawiciela na jednej z czterech płycin owej sławnej cembrowiny studziennej ze św. Wojciechem oraz wspomniany już wizerunek błogosławiącego Chrystusa na dwunastowiecznej mozaice $\mathrm{z}$ frontonu bazyliki. W X wieku zapewne żywa była jeszcze pogańska, asklepiadejska tradycja o świętości tego miejsca. Celem ujęcia jej w ramy chrześcijańskiego kultu przeorganizowano ruinę świątyni Eskulapa w bazylikę ku czci Tego, który „leczy wszystkie choroby i wszystkie słabości” (Mt. 9,35). Prawdopodobnie owa cembrowina została ustawiona w miejscu od wieków czerpanej wody, której przypisywano własności lecznicze. Że wodę tę czerpano tu nadal, zdają się świadczyć wytarcia górnego obrzeża studzienki, które unieczytelniły biegnącą wokól inskrypcję. Natomiast pojedyncze słowa wyryte na płycinach wyobrażających: Chrystusa, św. Bartłomieja, Ottona III lub II i św. Wojciecha - poczynając lekcję z prawej strony od głowy Chrystusa, a układające się w zdanie: + OS PUTEI SANCTI CIRCUNDAT ORBE ROTANTI + , świadczą wyraźnie o usankcjonowaniu tamtego starożytnego zwyczaju czerpania stąd „cudownej” wody. Zarazem te wyobrażenia świętych i wyryte słowa były apotropeum przeciw złym mocom; teraz mieli to sprawiać „ci święci” otaczający studzienkę ${ }^{51}$. Interesujący to przykład myślenia obrazowego i tak charakterystycznej dla średniowiecza kultury symbolicznej.

Uroczystość złożenia Wojciechowej relikwii na wyspie nastąpiła zapewne wkrótce po powrocie cesarza z Gniezna i Akwizgranu, więc po 1 listopada 1000 roku, a przed 16 lutego roku następnego (kiedy to cesarz musiał Rzym opuścić). Jak można wnosić z lakonicznego zapisu translatio reliquiarum była okazała. Odbyła się „, cum omni honore et diligentia et hymnis Dei”, z udziałem samego cesarza, biskupów, księży, mnichów, senatu i ludu rzymskiego. Uczestniczyło w niej zapewne wielu pamiętających i znających św. Wojciecha, np. biskup porteński kard. Benedykt. Jego osobiste związki z awentyńskim klasztorem są znane, natomiast $z$ Radzimem-Gaudentym, a zatem i z samym Wojciechem zdają się być poświadczone ${ }^{52}$. Cesarz wyposażył wówczas bazylikę licznymi, drogocennymi paramentami i instrumentami liturgicznymi. Z pewnością też złożył tu jeden z odpisów Vita Adalberti. Ale zarazem cesarz musiał zdawać sobie sprawę z tego, że same relikwie św. Wojciecha, choć pamiętanego dobrze

${ }^{51}$ Szczegółową analizę paleograficzną tych inskrypcji przeprowadził A. G ie ys zt or (Rzymska studzienka..., s. $23-25$ ).

52 Zob.: Miraculas. Alexii..., s. $260-262 ;$ S. Zak rzewski, Opactwo..., s. 84. A. Gie ys zt or (Rzymska studzienka ..., przypis 7) zauważył, że konfirmacja Grzegorza IX z 1236 r. dla biskupa Porto (A. Potth ast, Regesta pontificum Romanorum, Berolini 1874, I 10217) wzmiankuje rzymski kościól św. Wojciecha. Warto nadmienić, że we wspomnianym dokumencie cesarskim z 2 XII 999 r. (MGH Diplomata Ottonis III, s. 768 nr 339) obok Gaudentego, zarówno w protokole, jak i w liście świadków, występuje „Benedictus episcopus Portuensis ecclesiae”. Można przypuścić, iż ten porządek zapisu nie jest przypadkowy, ale może utrwala dawniejszy związek przyjaźni tegoż biskupa Porto z Adalbertem, opatem awentyńskim, poświadczony przez Miracula s. Alexii, a przelanej na osobę Gaudentego. 
w kręgu rzymskiej elity tego czasu i choć drogie jego sercu, nie mogły gwarantować wytworzenia się w Rzymie żywszego, jak to było w jego zamyśle, ośrodka kultu o znaczeniu uniwersalnym. W Rzymie dominował pietyzm najdostojniejszych apostołów Piotra i Pawła, patronów miasta, ponadto na każdym kroku napotykano tu mocno zakorzenioną cześć licznych męczenników. Dlatego też może starano się umocnić ten świeżo szczepiony kult Słowianina innymi relikwiami. Jeszcze latem 999 roku cesarz złożył był na wyspie przywiezione z Benewentu szczątki św. Bartłomieja, apostoła i męczennika, oraz Paulina z Noli. Znalazły się tu także relikwie innych wczesnochrześcijańskich świętych: Marcelina, bliskiego Maurycemu Egzyperansa i Sabina, a w roku 1000 sprowadzono tu „odkryte” właśnie pod Sorakte relikwie św. Abundiusza i Abundancjusza oraz Teodory Rzymianki, a dalej relikwie męczenników Marcjana i Jana, ojca i syna, których św. Abundiusz ochrzci1 ${ }^{53}$. Wszystkie te kolejne translacje relikwii świętych ,ad ecclesiam beati Adalberti”, odbywane równie uroczyście, jak pierwsza, były okazją do gruntowania kultu św. Wojciecha. Nie ustrzegło to jednak kultu Słowianiana przed rychłym jego zmierzchem na gruncie rzymskim.

Otton III, który wszystkie „rzymskie i longobardzkie prowincje trzymał w wierności i posłuszeństwie $\mathrm{z}$ wyjątkiem jednego Rzymu, który tak wyniósł i umiłował ponad wszystko" 54 , w połowie lutego 1001 roku musiał wraz z Sylwestrem II opuścić wieczne miasto, by nigdy już tu nie powrócić. Wielkanoc roku 1001 spędził w republice monastycznej św. Romualda w Pereum pod Rawenną, gdzie też w tym czasie ufundował jeszcze jeden kościół ku czci św. Wojciecha. Zmarł nagle 24 stycznia 1002 roku na zamku Sorakte, w trakcie prób odzyskania Rzymu. Gwiazda Krescencjuszów wzeszła na nowo. Gdy zwłoki cesarza w tajemnicy o jego zgonie wyprawiano do miejsca ich przeznaczenia w Akwizgranie, Sylwester II wrócił do Rzymu, ale zmarł już w maju roku następnego i spoczął na Lateranie. Plany realizacji ottońskiego systemu europejskiego upadły. Teraz też dość szybko - wyłączając Polskę, a od czasów Brzetysława i Czechy - wymowa ideowa kultu św. Wojciecha w Europie szybko poczęła słabnąćc5 ${ }^{55}$. Henryk II, który np. w Akwizgranie kontynuował i w roku

${ }^{53}$ O powyższym opowiadają m. in.: Gloria posthumae s. Bartholomei, [w:] Acta Sanctorum. Augusti. t. 5 s. 77 - 100; Translatio reliquiarum ss. Abundii et Abundantii (zob. wydanie A. Kolbergera, jw., s. $517-518$ ); C. Baronius, Annales..., t. 11, s. $401-402,414$.

${ }_{54}$ Kronika Thietmara, s. 212.

55 W Polsce kult św. Wojciecha jako patrona prymarnego nie ustał nawet po kanonizacji biskupa Stanisława. Był od początku tak mocno ugruntowany i wystarczający, iż - zauważa A. G i e y s zt or (w głosie dyskusyjnym zob. „Nasza Przeszłość” t. 69: 1988 s. 226 - 227) — „nie było już miejsca na świętego króla”, jak to było w przypadku licznych monarchów apostolskich wczesnośredniowiecznej Eruopy (np. Zygmunta burgundzkiego, Wacława czeskiego czy Stefana węgierskiego i in.). Również doniosłego znaczenia nabral kult św. Wojciecha w Czechach po zagrabieniu przez Brzetysława z Gniezna i przewiezieniu do pragi jego relikwii w roku 1038; zob. R. G rode cki, Rola św. Wojciecha w dziejach Polski i Czech, [w:] tegoż, Polska piastowska, opracowal i posłowiem opatrzył J. Wyrozumski, Warszawa 1969, s. 29 — 48 i komentarz bibliograficzny: s. 752 754. 
1005 ukończył fundację swego poprzednika ku czci św. Wojciecha, w Rzymíe jednak nie miał tej szansy ${ }^{56}$.

Sladem kultu św. Wojciecha w poottońskim Rzymie jest prawdopodobnie jeszcze z tamtych czasów pochodząca ta kopia Żywota, której losy wiążą się z klasztorem przy św. Cecylii na Zatybrzu ${ }^{57}$. Zresztą dzieje samej wyspy w czasach poottońskich są szczególnie burzliwe. To miejsce pośrodku rzeki, na którym u schyłku X w. szukali odosobnienia mnisi, dla swych naturalnych walorów obronnych rychło stało się strategicznym punktem bezpiecznego schronienia. Do dziś stoi na wyspie wieża mieszkalna $z$ tamtych czasów, zwana Torre Caetani lub Torre della Pulcella (od białej kobiecej główki antycznej rzeźby tkwiącej w murze). Tu w roku 1014 próbował się schronić Henryk II przed Krescensjuszami. W burzliwym dla papiestwa wieku XI zapisała się ta benedyktyńska wysepka „między dwoma mostami” jako schronienie papieży. Tutaj w roku 1058 zbiegł Hildebrand w czasie elekcji Mikołaja II, tu Matylda Toskańska w roku 1086 - 1087 udzielała schronienia Wiktorowi III, tu następnie w roku 1088 - 1089 wycofał się Urban I, a potem i Paschalis II w roku $1105^{58}$.

W ciągu XI wieku bazylika na wyspie nosi tytul Sancti Adalberti lub Sancti Adalberti et Paulini. Natomiast za Paschalisa II, który podupadłą bazylikę podźwignąl, wspomina się jego fundatora Ottona, ale wspomnienie św. Wojciecha wypiera kult św. Bartłomieja. Wymownie świadczy o tym dochowana w portyku głównym inskrypcja z roku $1113^{59}$. Od tego czasu bazylika zmieniła wezwanie, a do niego poszła kolejna nazwa wyspy: Isola San Bartolomeo, oraz mostu łączącego ją z Trastevere: Ponte San Bartolomeo. Obydwie te nazwy ugruntowały się w ciągu XII wieku i przetrwały do dziś.

Na zakończenie jeszcze krótko o dalszych losach rzymskich relikwii św. Wojciecha. W XIV wieku jakąś ich cząstkę zabrano stąd na Warmię ${ }^{60}$. Z lat 1547 - 1601 pochodzą poświadczenia obecności drewnianego relikwiarza podróżnego z napisem: „Corpus S. Adalberti et SS Superantii et Marcellini”. W zapiskach rekognicyjnych występowało też czasem niezidentyfikowane „ramię”, to znów zwano je ramieniem św. Paolina. Relikwiarz ten ulokowano pod ołtarzem w przerobionej w latach $1550-1555$ z zakrystii, poświęconej św. Wojciechowi kaplicy. W roku 1626 kaplicę tę własnym sumptem odrestaurowała i wzięła w korporacyjną opiekę - jak świadczy pamiątkowa inskrypcja -

${ }^{56}$ Zob.: A. Gie ys zt or, Rzymska studzienka..., s. 27; J. Ka rw a sińs k a, Studia nad Żywotami, 2:1958 s. 51 .

57 Zob.: tamże, s. 72.

58 Por. C. Cecch elli, La basilica ottoniana ..., s. $29 \mathrm{nn}$.

59 Inskrypcja ta wielokrotnie była publikowana - zob.: C. B a ronius, Annales..., s. 402; Fra. Casi mir o R o m a n o, Storia della chiesa di S. Maria in Aracoeli, Roma 1744, s. 315; C. Cec ch elli, La basilica ottoniana..., s. 29; A. Si s t i, La basilica di San Bartolomeo..., s. 6; A. Gi ey s z t or, Rzymska studzienka..., s. 28 (tutaj też, w przypisie 7, referencje źródłowe przemiany wezwania bazyliki).

60 Zob. przyp. 39. 


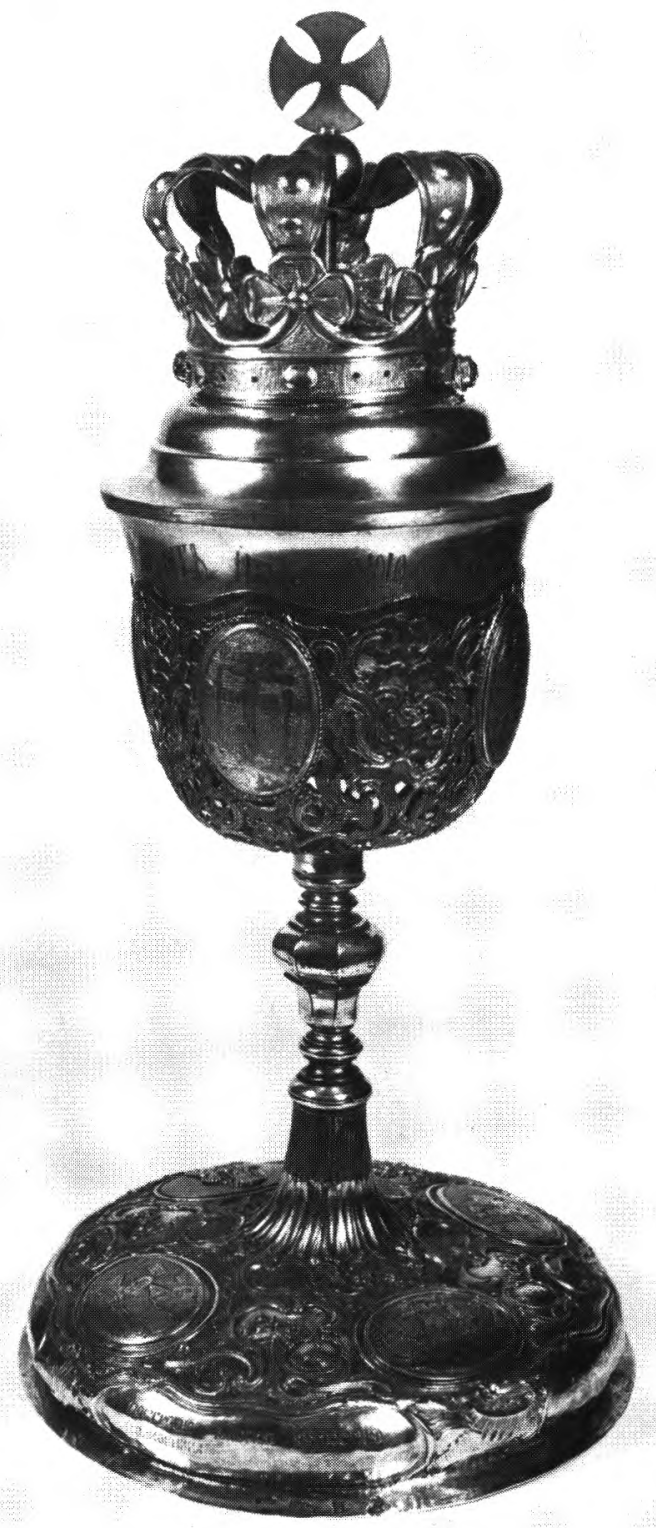

1.

1-4. Puszka z roku 1761 i jej poszczególne plakietki. Kościół św. Katarzyny w Krakowie (fot. J. Langda). 


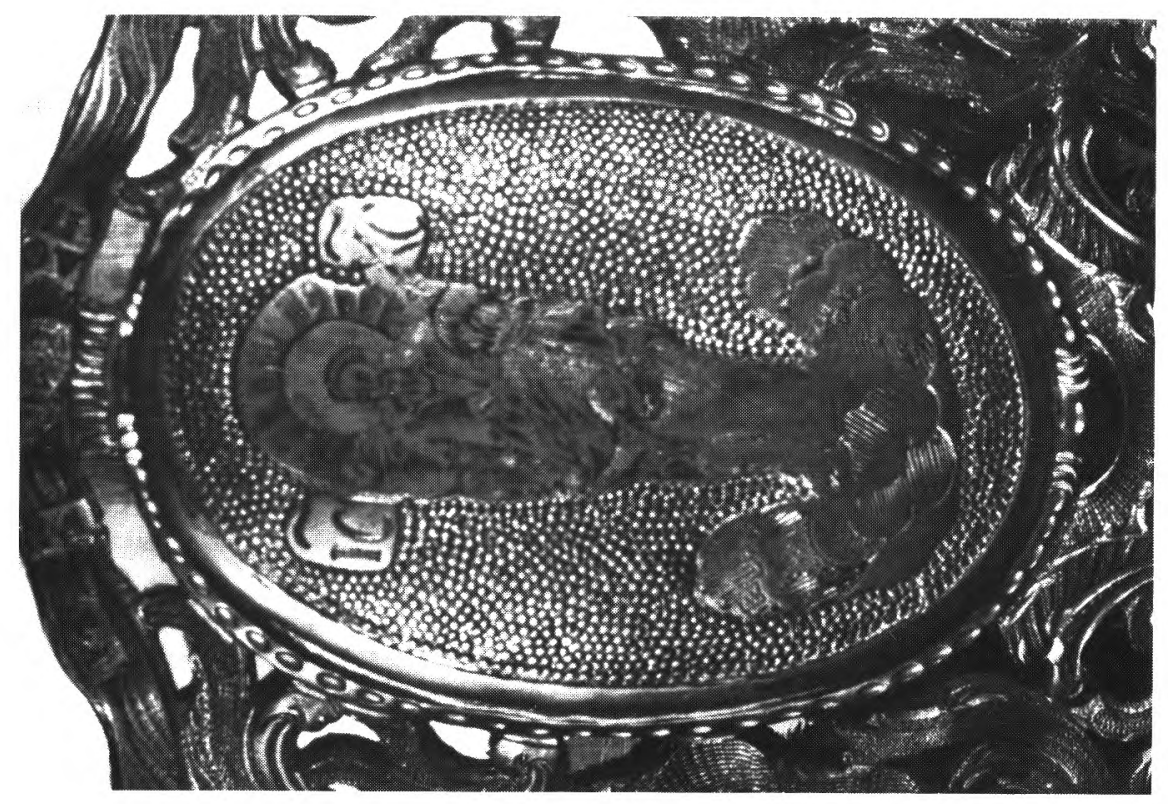

$\dot{m}$

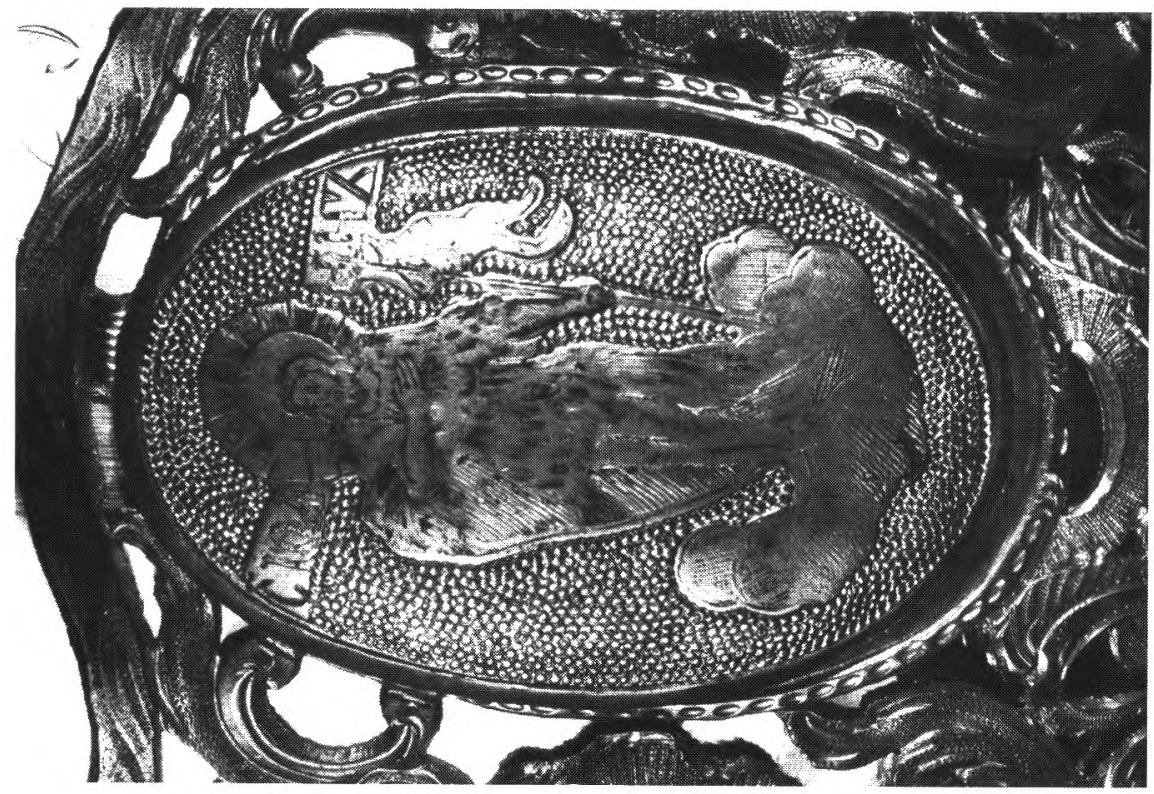



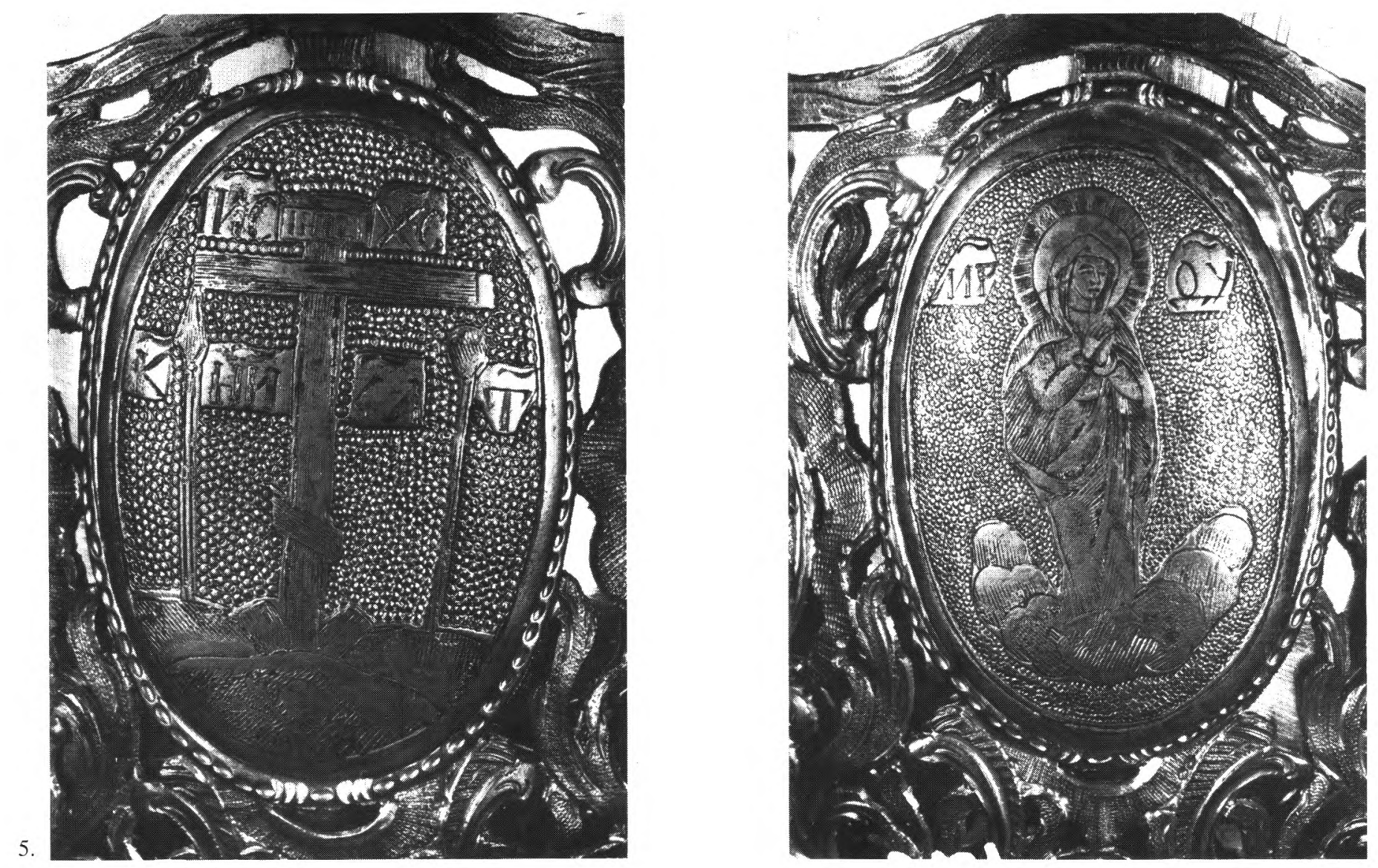

5-8. Stopa puszki z roku 1761 i jej poszczególne plakietki (fot. J. Langda). 


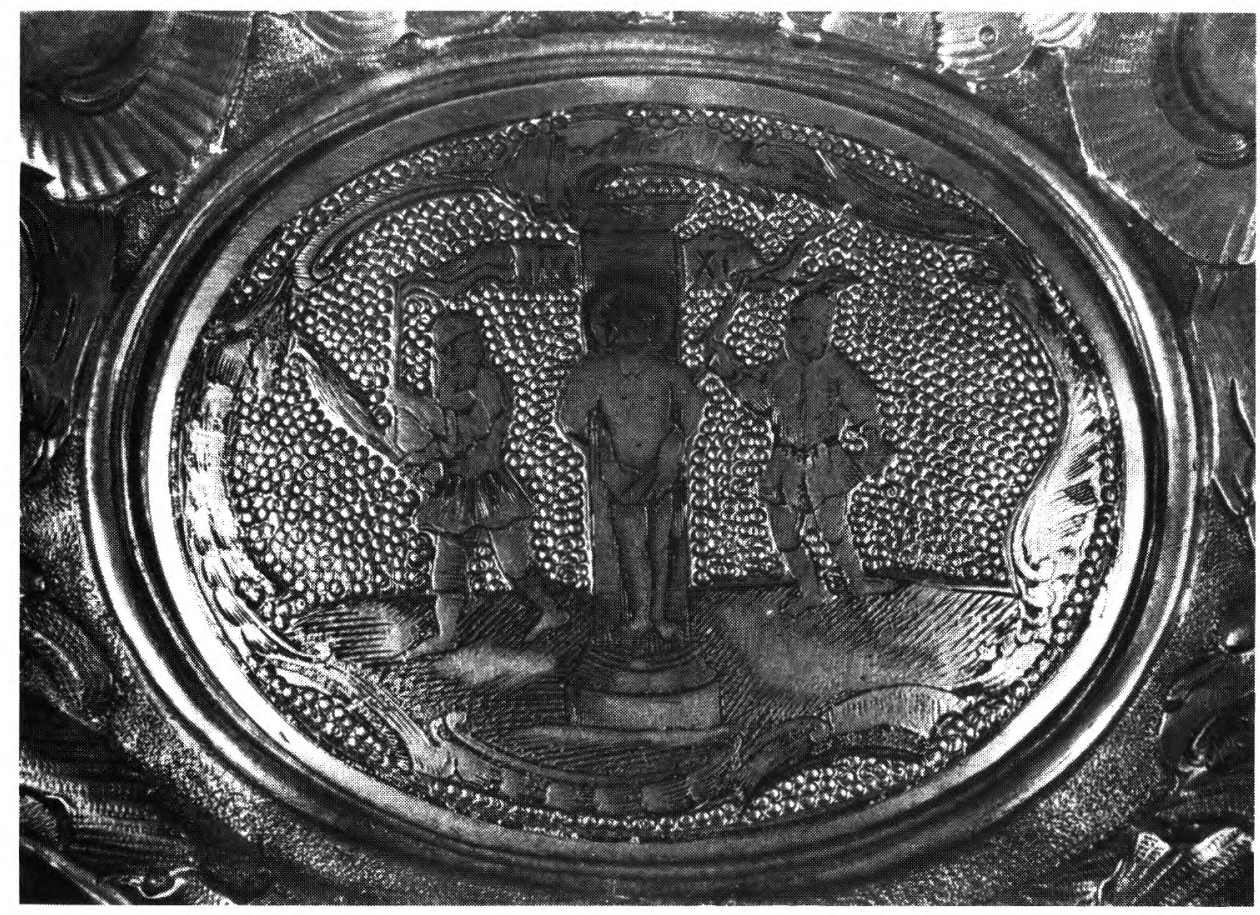

6.

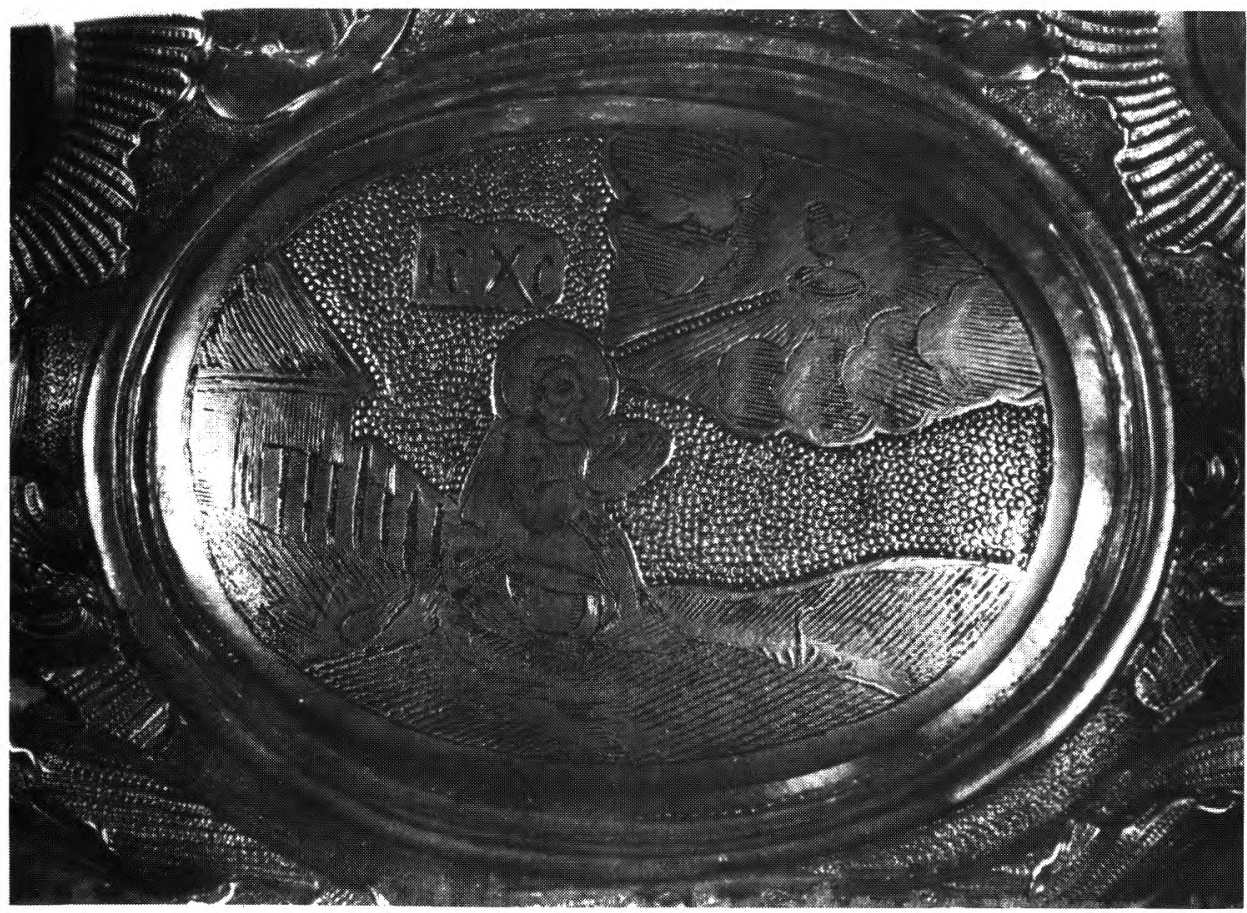




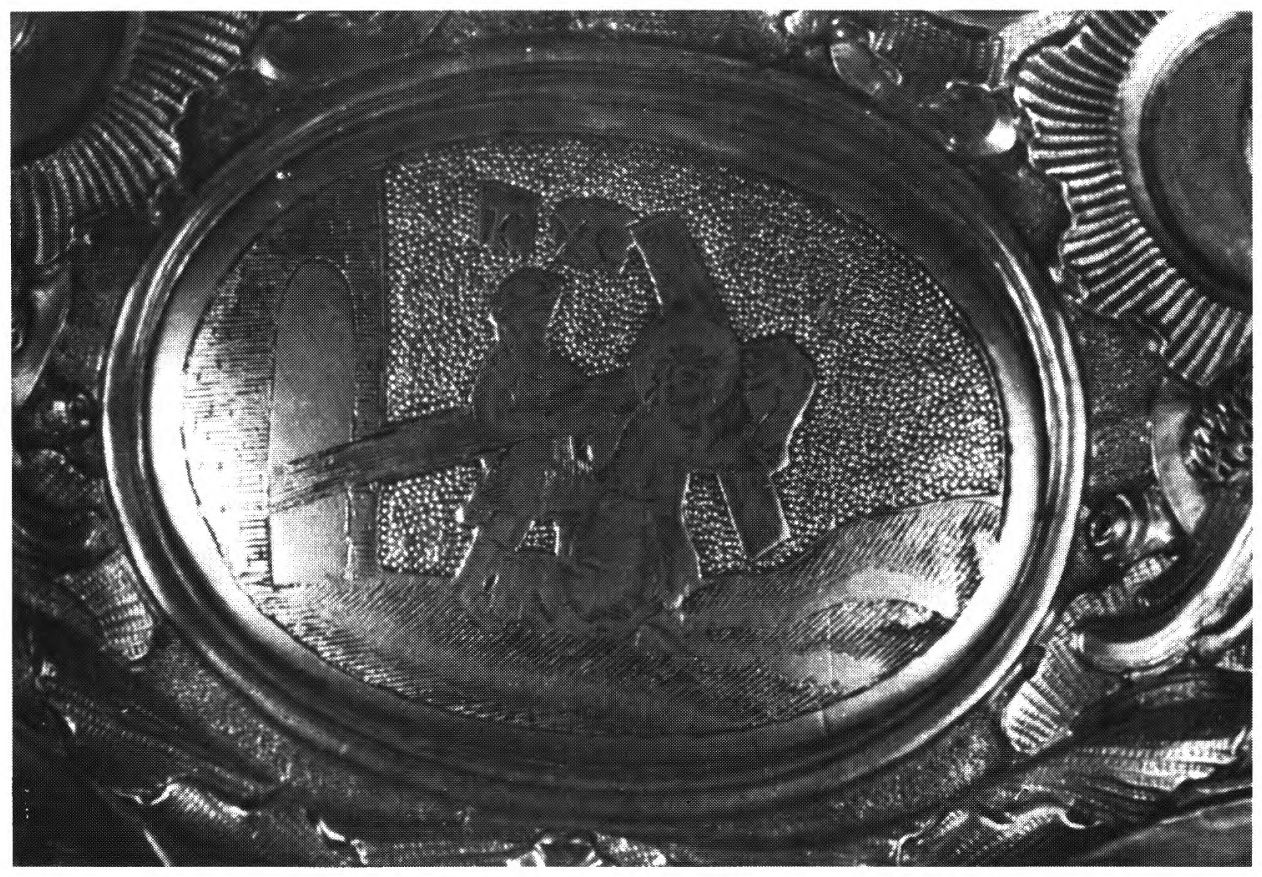

8.

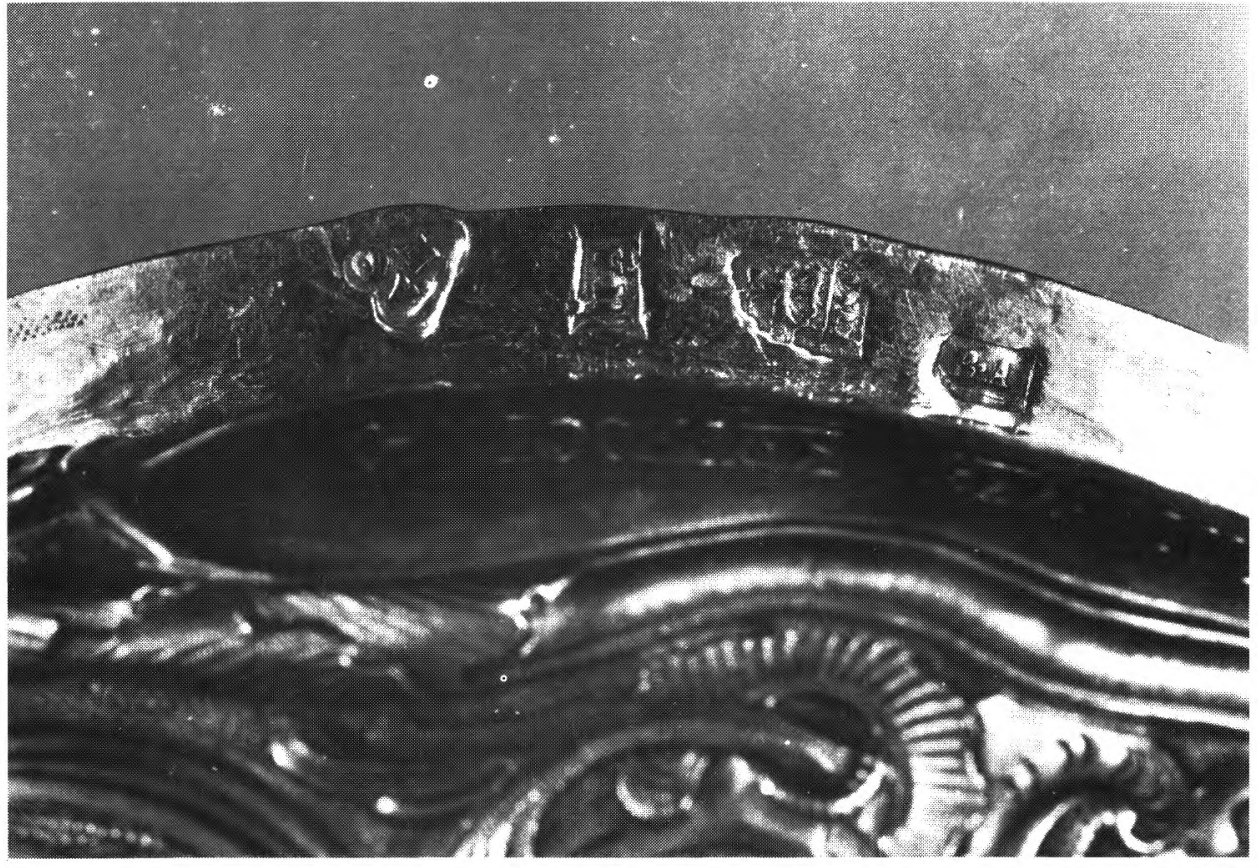

9. Znaki złotnicze na brzegu stopy puszki z r. 1761 (fot. J. Langda). 


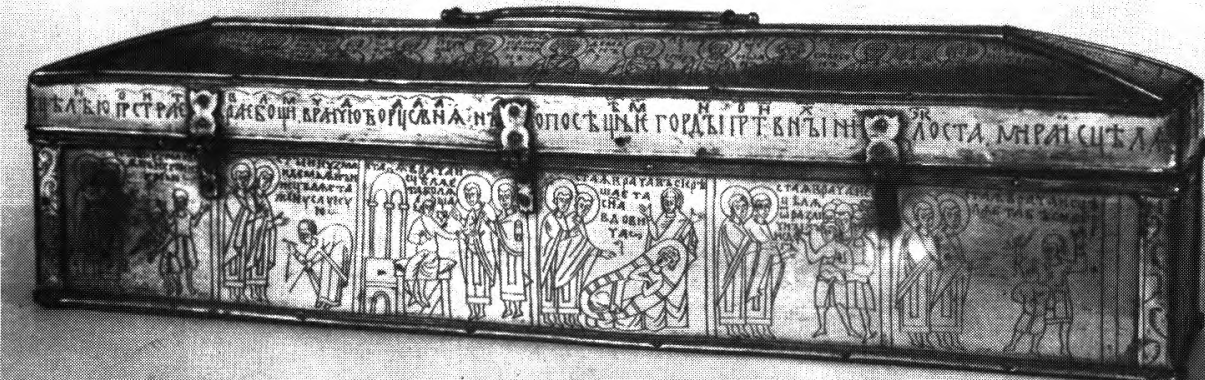

10.

10-12. Ruska skrzyneczka z początku XV wieku w kościele Mariackim w Krakowie (fot. W. Wolny, P. Maliszewski, M. Moraczewska).

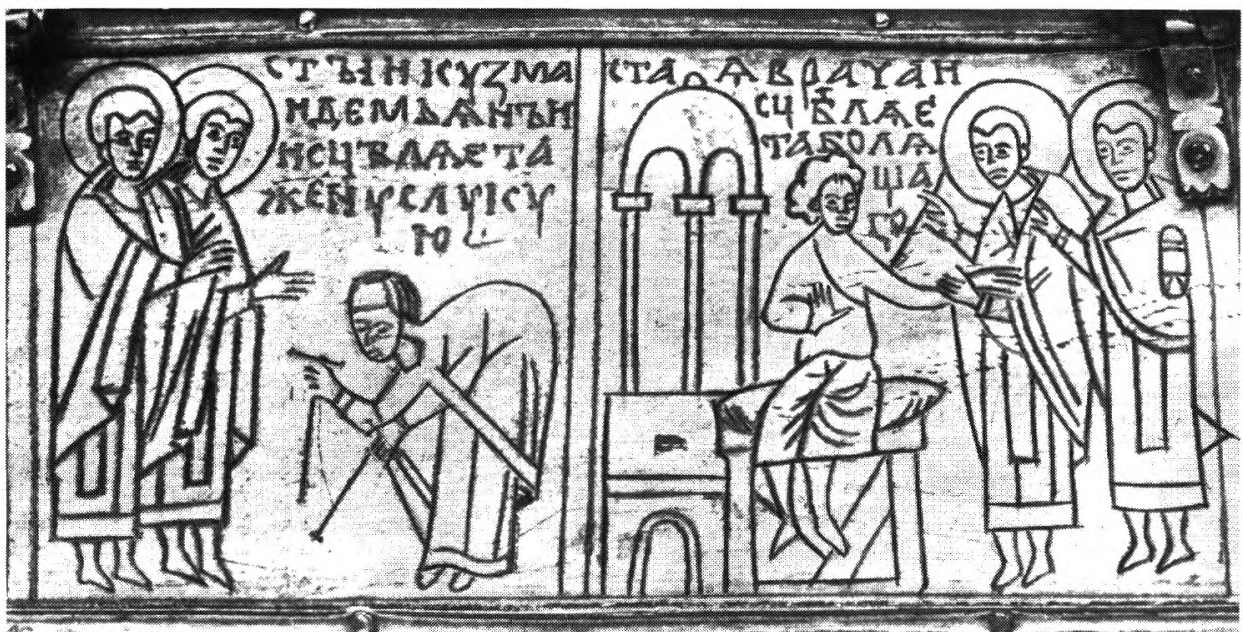

11. 


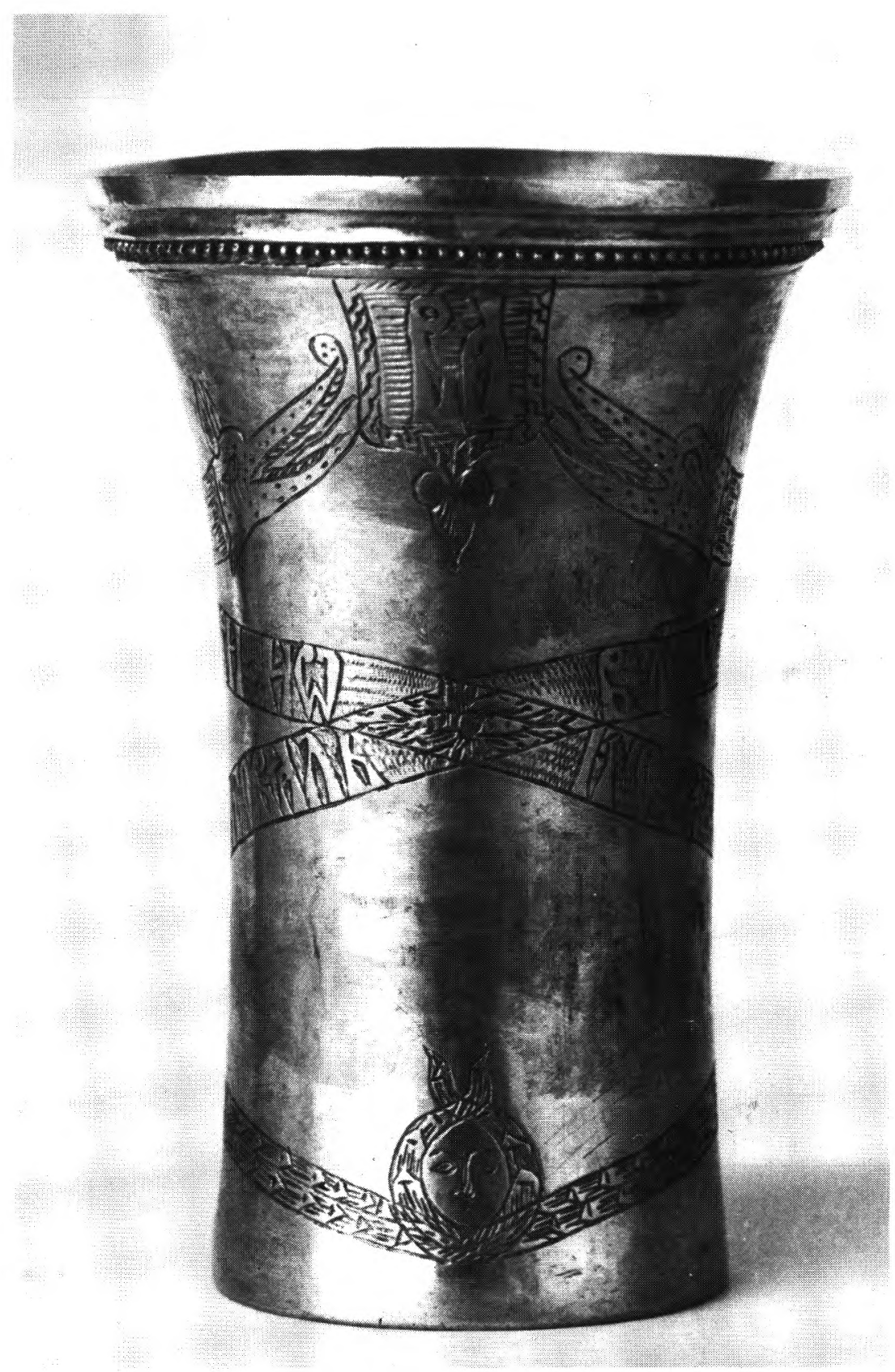

12.

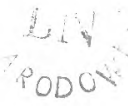




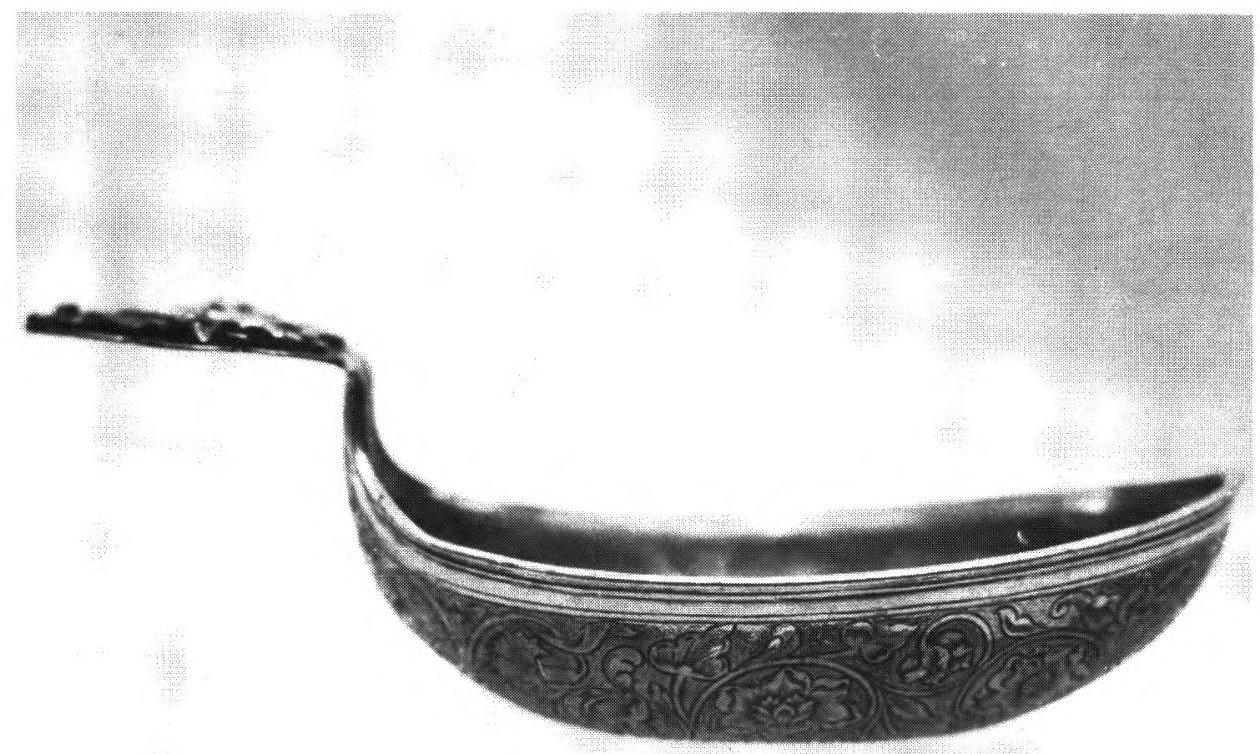

13. Kubek z roku 1595 w Zbiorach Czartoryskich w Krakowie (fot. J. Książek).

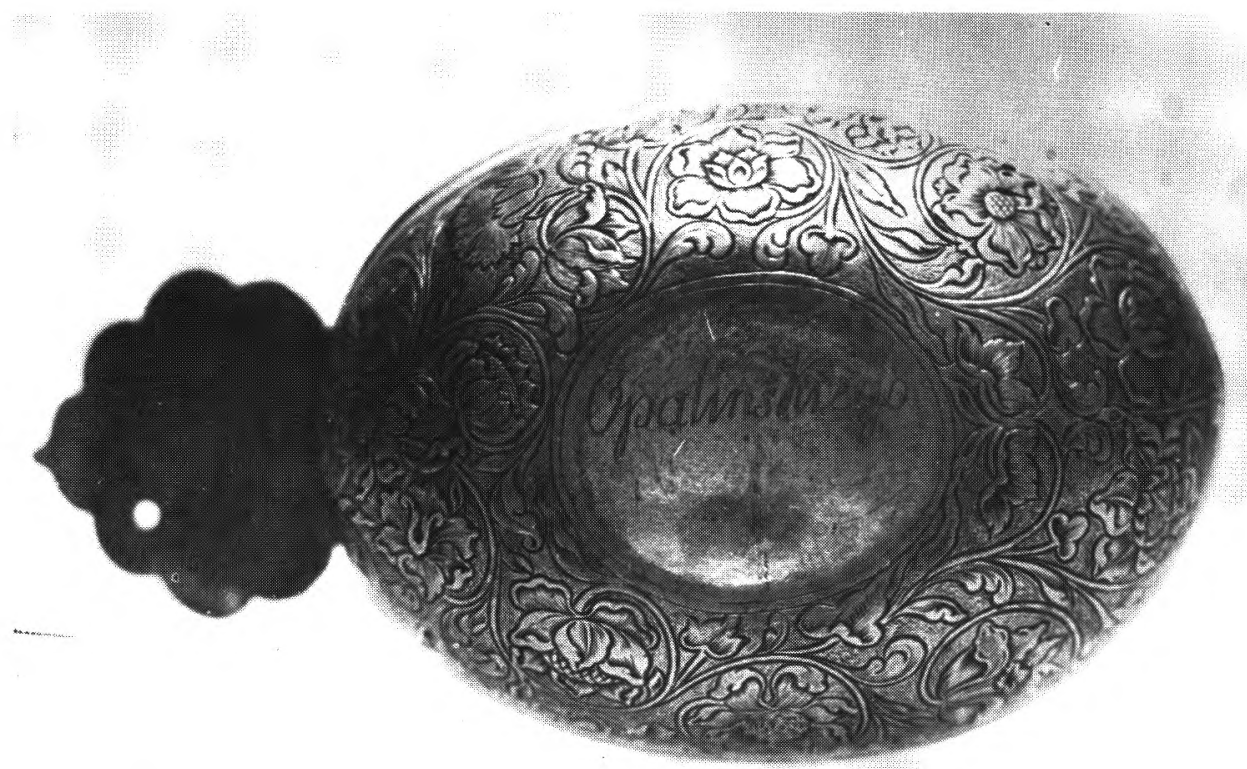

14. Czara z drugiej połowy XVII wieku w Zbiorach Czartoryskich w Krakowie (fot. J. Werner). 
wspólnota młynarzy (Universitas Molendinatorum) ${ }^{61}$. Dawnego patrona tej kaplicy jednak nie zapomniano, skoro bractwo to, fundując w roku $1655 \mathrm{obraz}$ do ołtarza, poleciło przedstawić na nim św. Wojciecha z palmą męczeństwa in pontificalibus. W ten sposób św. Wojciech stał się niejako patronem rzymskiej korporacji młynarzy. Gdy 22 stycznia 1852 roku za zgodą kurii rzymskiej otwarto ów drewniany relikwiarz, znaleziono tam drobną notatkę z 1713 roku, że jest to ramię św. Wojciecha ${ }^{62}$. Z XVIII w. pochodzi również przechowywany w tym kościele drewniany relikwiarz św. Wojciecha w kształcie popiersia. $\mathrm{Z}$ tego wieku mamy też poświadczenie Wojciechowej relikwii w kościele Santa Maria in Aracoeli na Kapitolu, która najpewniej dostała się tu z awentyńskiego klasztoru63. Po kradzieży relikwii głowy św. Wojciecha w Gnieźnie w roku 1928, kard. August Hlond otrzymal cząstkę z wyspy ${ }^{64}$. W roku 1973, w tysiąclecie diecezji praskiej, Czesi wmurowali w antepedium rzymskiego ołtarza św. Wojciecha bilingwiczną, czesko-łacińską inskrypcję pamiątkową: „Sancto Adalberto anno milesimo dioecesis pragensis + 973 - 1973 + Svatemu Vojtechu $\mathrm{k}$ tisicileti prażske diecese". Obecny, widoczny pod mensą relikwiarz w formie metalowej skrzynki z krzyżem, wykonano w 1976 roku według projektu A. Martiniego, franciszkanina z tutejszego klasztoru.

Jakkolwiek więc zamierzona na uniwersalną skalę propaganda kultu św. Wojciecha uległa nagłemu zahamowaniu, a wzniesione ku jego czci przybytki nad Tybrem i w Kampanii rzymskiej, a także nad Padem, nad Mozą, Renem i nad Dunajem na Węgrzech, szybko (wyłączając Polskę i Czechy) utraciły swe ideowo-polityczne znaczenie, to jednak te jego relikty są dziś swoistym świadectwem, jako elementy konstrukcyjne ottońskiej budowy nowej Europy - budowy, która runęła, nim ledwo zaczęto ją wznosić. Ponadto znaczenia wpisanej w jej plan pielgrzymki Ottona III ad limina Adalberti - do Gniezna roku tysięcznego dla dziejów Polski przecenić się nie da. Jej świadectwem jest i ta rzymska tradycja uczepiona wyspy „inter duos pontes”.

${ }^{61} \mathrm{Na}$ ścianach tej kaplicy (Capella del'Arte dei Molinari) malatury z XVII wieku ukazują młyny wodne na Tybrze w okolicy Wyspy. Widać je też w znacznej liczbie w tym miejscu na starych mapach Rzymu, np. Pianta di Roma del Falda z 1675 czy Pianta di Roma del Nolli z 1748 roku.

62 Zob. A. Przeździ e cki, Ślady Bolestawów polskich po obcych krajach, Warszawa 1853, s. 2; I. Polkowski, Groby i pamiqtki polskie w Rzymie, Drezno 1870, s. 3; W. S mocz y ński, Rzym, jego kościoły i pamiatki. Upominek pielgrzymom polskim, Kraków 1902, s. 191 - 192.

63 Notuje to Fra. Casimi ro Ro ma no, Storia della chiesa..., 315. Awentyn mógł mieć jakąś cząstkę Wojciechowych relikwii wcześniej niż wyspa, przywiezioną do Rzymu przez Radzima-Gaudentego. Z tej cząstki mógł Otton obdzielić te kaplice i ołtarze na terenie Italii, które erygował ku jego czci jeszcze przed rokiem 1000.

${ }^{64}$ Por. J. Now a cki, Z dziejów kultu św. Wojciecha w Polsce, [w:] Swięty Wojciech 997 1947. Księga pamiątkowa, Gniezno 1947, s. 332 (przypis 11). Uściślenie tej informacji zawdzięczam ks. Wladysławowi Zientarskiemu, dyrektorowi Archiwum Archidiecezjalnemu w Gnieźnie. Archiwum to jednak żadnych akt sprawy nie posiada. 


\section{OTTOS STIFTUNG ZU EHREN ST. ADALBERTS AUF DER TIBERINSEL}

\section{Zusammenfassung}

Die heute stark barockisierte Basilika San Bartolomeo al Isola Tiberina, ursprünglich St. Adalbert Kirche, hat laut der in Rom seit langem bestehenden Ansicht Otto III. gestiftet, um dorthin die aus Gnesen im Jahre 1000 mitgebrachten Reliquien St. Adalberts zu verwahren. Dieser Beitrag will an die Genese dieser Kaiserstiftung erinnern. Als Ausgangspunkt der geschichtlichen Erwägungen kann man die Peregrination des Kaisers nach Gnesen annehmen, die unternommen wurde infolge des Todes des Bischofs Adalbert Słownikowic, den er am 23. April 997 während der Missionierung der heidnischen Preußen erlitten hatte. Um es deutlich zu zeigen, was diese römische Stiftung zu Ehre des Freundes von Kaiser in Ottos Plänen bedeutete, welchen Sinn dessen Kultus für Rom und Italien und welchen für das ganze Kaisertum haben sollte, müßte sie in einem breiteren Konte der Geschehnisse am Ende des ersten Jahrtausends dargestellt werden. Der Drang des römischen Adels nach Befreiung von der kaiserlichen Macht der Ottonen drohte immer mit neuen Auseinandersetzungen. Das blutige Jahr 998, in dem Crescentier II hingerichtet wurde, hatte sowohl Rom der Familie Crescentier als auch Otto III. tief erschüttert. Zugleich kam die Nachricht vom Tode Adalberts, für den Kaiser eine niederdrückende Nachricht, jedoch sie löste bald konstruktive Pläne und Wirkungen aus. Dauerhaftes Gedenken kaiserlichen Freundes Adalbert, konnte sowohl in der Benediktinerabtei St. Bonifatius und Alexius auf dem Aventin, als auch in den vom Kaiser unterdrückten Kreisen der römischen Elite zum Aufbau guter Verhältnisse in Rom führen. Die Abfassung der Hagiographie St. Adalberts, seine Heiligsprechung und Stiftungen zu seiner Ehre in Italien, mit Benediktinerkreisen verbunden jedoch von Crescentier verleiht, all das sollte diesem Ziel dienen. St. Adalbert sollte zum Schutzpatron des Kaisers werden bei der Realisierung seiner Konzeption Renovatio Imperii Romani und Erweiterung dessen Grenzen, verstanden als Bau einer Civitas Dei auf Erden. Die Wallfahrt des Kaisers Otto III. nach Gnesen und ihre zweite Etappe - Aachen (wo der Grab Karls des Großen entdeckt wurde), gehörten eindeutig zu dem universellen Plan der Erneuerung (renovatio).

Man vermutet, daß der Kaiser ursprünglich den ganzen Körper St. Adalberts aus Gnesen mitnehmen wollte, jedoch er mußte sich lediglich mit dem Arm des Heiligen zufriedengeben, den ihm Bolesław Chrobry - der Hauptdistribuent der Reliquien und der erste Verkünder des Kultus St. Adalberts geschenkt hatte. Die Wahl solcher Partikel zur Schenkung von Bolesław für den Kaiser hat eine symbolische Bedeutung. Bolesław, der seit dem Gnesener Treffen durch ein formelles Abkommen mit Kaiser verbunder war, wurde zu einem Mitausführenden seiner Ideen.

Die Reliquien des slawischen Heiligen legte der Kaiser in einer ganz besonderen Stätte in Rom - auf der Tiberinsel in der dort früher gebauten St. Salvator Kirche, wo sich seit 986 der von Gregor aus Porticello gegründete Benediktinerkloster der Aventinabtei befand. Die Insel selbst war auch Eigentum dieser Abtei kraft der Verleihung von Johannes Sohn des Demetrius (987), was durch ein kaiserliches Generalprivilegium vom Jahre 996 bezeugt wurde. Obwohl es reichlich Spuren Adalberts Angedenkens auf dem Aventin gab, wurde zur Hauptstätte des Kultus dieses Slaven in Rom die ihm gewidmete Basilika auf der Insel, wo die von Otto aus Benevento mitgebrachten Reliquien des Apostels St. Bartolomäus gelegt wurden. Die Niederlegung der Reliquien St. Adalberts auf der Tiberinsel wurde in der ältesten Hymne zu Ehren St. Adalberts, entstanden in Deutschland um 1002, erwähnt, auch in der aus der 2. Hälfte des 11. Jahrhunderts stammenden Interpolation des Textes $\mathrm{C}$ des Chronik von Ademar de Chabannes und auch im Text Translatio reliquiarum Abundii et Abundantii über Niederlegung auch auf der Insel der von Otto an Soracte eben entdeckten Reliquien von Abundius und Abundantius. Wann auch der letztgenannte Text zum ersten Mal aufgeschrieben worden sei, unterliegt es keinem Zwifel, daß er als Urkunde, die die sich in Rom um 1001 verbreiteten Nachrichten wiederspiegelt hatte, völlig glaubwürdig ist. 
Dieser Text läßt auch erkennen die Pracht der kaiserlichen Festlichkeiten, die die Niederlegung der Reliquien St. Adalberts auf der Tiberinsel begleiteten. Davon wurde dann berichtet in einer der Veröffentlichungen Miracula S. Adalberti (13. - 15. Jh.) in dem Königsberger Manuskript (13. - 14. Jh.), in der Chronica Polonorum und in der Chronica principum Polonorum (14 - 15. Jh.).

Die Verbreitung des Kultus St. Adalberts im Kaiserreich Ottos samt der frommen Stiftungen zu seiner Ehre wurde gehemmt (ausgeschlossen Polen und Böhmen von der Zeit Brzetysławs an) und hatte ihre politisch-ideelle Bedeutung nach dem Tode Ottos III. verloren. Der Versuch, den Kultus St. Adalberts dauerhaft in Rom einzuflößen, ist nicht gelungen. Der Name Adalberts, mit dieser Kirche Roms verbunden, ist nicht über das 11. Jh. hinweg geblieben. Damals wurde die Basilika schon auf immer St. Bartolomäus geweiht. Lediglich eine Kapelle der Basilika hat den Namen St. Adalberts behalten, vom 17. Jh. an unter dem Schutz des römischen Müllerverbandes. 